\title{
COMMENT
}

\section{CONTINUATION AND REPRESENTATION OF CLASS ACTIONS FOLLOWING DISMISSAL OF THE CLASS REPRESENTATIVE}

Since 1966, the amended class action procedure of rule 23 of the Federal Rules of Civil Procedure ${ }^{1}$ has become one of the principal tools for enforcing plaintiffs' rights and protecting constitutionally guaranteed civil liberties. ${ }^{2}$ When invoked on behalf of a definable group of plaintiffs, the class action may be used to obtain, in a single proceeding, broad scale rehef for the benefit of the entire class. The utility of the class action remedy, however, depends upon the extent to which the federal courts are willing and able to designate the clains of such groups as appropriate subjects for class action treatment. ${ }^{3}$ Util-

1. Fed. R. Crv. P. 23.

Rule 23 was substantially amended in 1966 to resolve uncertainties associated with the former rule and to provide an effective vehicle for obtaining broad scale relief. See Proposed Amendinents, 39 F.R.D. 73, 94-107 (1966).

HEREAFTER THE FOLLOWING CITATIONS WILL BE USED IN THIS COMMENT:

J. MOORE, Federal Practice (2d ed. 1948) [hereinafter cited as Moore];

C. Wright \& A. Muller, Federal Practice and Procedure (1969) [heremafter cited as WRIGHT \& MILLER].

2. See Huff v. N.D. Cass Co., 468 F.2d 172, 179 (5th Cir. 1972). See generally 3B MOORE II 23.40, at 23-653; 7 WRIGHT \& MILLER § 1771; 7A Wright \& MILLER $\S$ 1776; Advisory Committee's Note to Rule 23, 39 F.R.D. 98, 102 (1966).

The class action has become a significant tool for the enforcement of the Civil Rights Act of 1964, 28 U.S.C. $\$ 1447 ; 42$ U.S.C. $\$ \S 1971$, 1971a-1975d, 2000a to h-6 (1970), especially the employment discrimination provision, 42 U.S.C. $\$ 2000 \mathrm{e}$ (1970). See generally Donelan, Prerequisites to a Class Action under New Rule 23, 10 B.C. IND. \& CoM. L. REv. 527, 544 (1969); Miller, Class Actions and Employment Discrimination under Title VII of the Civil Rights Act of 1964, 43 Miss. LJ. 275 (1972); Subrin \& Sutton, Welfare Class Actions in Federal Court, 8 HaRv. Civ. Rights-Crv. LIB. L. Rev. 21 (1973); Wright, Class Actions, 47 F.R.D. 169, 178 (1969); Note, Title VII and Postjudgment Class Actions, 47 IND. L.J. 350 (1972).

3. A basic philosophical point of departure in class action decisions is whether federal class action practice should be encouraged. See, e.g., La Mar v. H \& B Novelty \& Loan Co., 489 F.2d 461, 463-68 (9th Cir. 1973). Nuinerous commentators have spoken out against the class action, calling it an engine of destruction which is weighted too heavily in favor of the plaintiff and which presents unjustifiably ineffective procedures for doing mass justice. See generally Katarincic \& McClain, Federal Class Actions Under Rule 23: How to Improve the Merits of Your Action Without Improving the Merits of Your Claim, 33 U. PrrT. L. REv. 429 (1972); Pollack, Class 
ity also depends upon the strictness of the standards applied by the court for determining the fitness of the asserted class representative to seek relief on behalf of the class. ${ }^{4}$

Subsections (a) and (b) of rule 23 posit the fundamental standards to be used in determining whether a claim can qualify for class action treatment. ${ }^{5}$ However, these sections do not deal comprehensively with the criteria which an individual inust satisfy in order to represent the class in court. ${ }^{6}$ The absence of any such clear criteria has made it

Actions Reconsidered: Theory and Practice Under Rule 23, 28 Bus. Law. 741 (1973); Simon, Class Actions-Useful Tool or Engine of Destruction, 55 F.R.D. 375 (1972). Other writers have countered with arguments that proposals to restrict class actions are premature and that the practical problems of managing effective class litigation are superable. See Ashe, Class Action: Solution for the Seventies, 7 NEw ENo. L. REv. 1 (1971); Berger, Class Actions, 77 Case \& Comment 26 (1972); Pomerantz, New Developments in Class Actions-Has Their Death Knell Been Sounded?, 25 Bus. Law. 1259 (1970); Weinstein, Some Reflections on the "Abusiveness" of Class Actions, 58 F.R.D. 299 (1973). But since it was originally envisioned that the fundamental mechanism of rule 23 shonld be permissively construed, see generally Advisory Committee's Note to Rule 23, supra note 2, these basic attitudes for or against class action procednre should not color an evaluation of the analysis herein.

4. Cf. LaSala v. American Sav. \& Loan Ass'n, 5 Cal. 3d 864, 489 P.2d 1113, 97 Cal. Rptr. 849 (1971). See also Degnan, Foreword: Adequacy of Representation in Class Actions, 60 CAIIF. L. Rev. 705 (1972).

5. The prereqnisites applicable to every class action are enumerated in FED. R. Crv. P. 23(a):

One or more members of a class may sue or be sued as representative parties on behalf of all only if (1) the class is so nnmerous that joinder of all members is impracticable, (2) there are questions of law or fact common to the class, (3) the claims or defenses of the representative parties are typical of the claims or defenses of the class, and (4) the representative parties will fairly and adequately protect the interests of the class.

Additionally, a class action must also qnalify under one of the three subsections of rule 23 (b) in order to be maintainable. Rule $23(b)(1)$ authorizes the use of the class action where a series of individual suits might subject the defendant to conflieting adjudications or inight impair the abihty of separate members of the class to protect their rights; subsection (b)(2) allows class actions in cases where the appropriate remedy is predominantly injunctive or declaratory relief with respect to the class as a whole; subsection (b) (3) permits individual damages to be sought on behalf of all the members of a class provided that common questions of law and fact predominate over individnal matters in the case and that the class action is a superior mechanism for the fair and efficient adjudication of the controversy. Although the prerequisites for a class action are clearly set forth in these sections of the rule, the courts must nonethcless use their discretion in determining whether a particular action qualifies. See Gold Strike Stamp Co. v. Christensen, 436 F.2d 791 (10th Cir. 1970); City of New York v. International Pipe \& Ceramics Corp., 410 F.2d 295 (2d Cir. 1969). See generally 7A WRIOHT \& MIILER § 1785, at 134.

6. The only specific prerequisite of the rule directly applicable to the representative parties is rule 23 (a)(4)'s reqnirement that they will "fairly and adeqnately protect the intercsts of the class." Not only is this reqnirement unaccompanied by other criteria governing the selection of the class representative, but also its own meaning is not further elahorated elsewhere in the rule. See notes 122-53 infra and accompanying text. 
especially difficult to deal with the situation which arises when the only named representative in a class action, after asserting a justiciable claim on his own behalf, ${ }^{7}$ loses that individual cause of action prior to a full determination on the merits of the claim presented on behalf of the class. ${ }^{8}$ In this situation it is unclear whether the class aspect of the action should be allowed to continue, and if so, whether the unsuccessful individual party should be allowed to continue serving as the representative of the class interests. ${ }^{9}$ Since the subject has been treated imconsistently and unsystematically by the courts, this Comment will attempt to clarify this aspect of federal class action practice.

In order to define the scope of the problem, this Comment will first describe the various ways in which the problem typically arises. Through examining a number of recent decisions, it will be shown that a conflict presently exists among the courts which cannot be resolved or explamed away merely on the basis of factual differences among the cases. Instead, the courts seem to have proceeded, to a significant degree, on an ad hoc basis, which has afforded them the discretion necessary for the dispensation of individual justice, but which has simultaneously resulted in inconsistent judicial treatment and has created the appearance of judicial overreaching. In order to clarify this aspect

It should be noted, however, that the extensive 1966 amendments to rule 23 did substantially shift the rule's emphasis in this regard. See note 9 infra.

7. As to the importance of the class representative's initially asserting a justiciable personal claim, as well as a justiciable claim on behalf of the class, see notes 23-25 infra and accompanying text.

8. The problem usually arises when only one named plamtiff is mvolved. If other representative plaintiffs remain before the court, then, regardless of the dismissal of one of them, the ability of the remaining representatives to continue representing the class action is unimpaired. See Cypress v. Newport News Gen. \& Nonsectarian Hosp. Ass'n, 375 F.2d 648 (4th Cir. 1967). See also Arkansas Educ. Ass'n v. Board of Educ., 446 F.2d 763 (8th Cir. 1971); Jacobs v. Board of School Comm'rs, 349 F. Supp. 605 (S.D. Ind. 1972).

9. It seems likely that the 1966 amendments to rule 23 significantly enhanced the probability of this issue arising as a real problem for the courts. Prior to 1966 , rule 23 predicated the right to represent a class upon the conceptual character of the right sought to be enforced. See Advisory Committee's Note to Rule 23, supra note 2. Thus, a named plaintiff who himself had been determined to have no enforceable right in the action would be an unlikely candidate as a continuing representative of the class. By describing the occasions for maintaining class actions in terms such as the typicality of claims presented and the type of remedy sought, the current version of the rule has shifted its criteria towards the relationship which exists between the representative in the action and the class which he purports to represent. See generally Wright, supra note 2, at 177. Thus a named representative, who has lost on his personal claim and thereby no longer has a personal right to be enforced in the action, may nevertheless continue to be otherwise closely related to the class and may thereby be found an adequate representative to continue the action on behalf of the class. See note 59 infra and accompanying text. 
of the law, this Comment will suggest the use of an analytical approach which reduces this procedural problem to two distinct questions: (1) when can a class action be recognized as an action imdependent of a given representative's cause of action, and (2) upon which characteristics of the class representative is the adequate representation of a class action predicated? It will be demonstrated that these two inquiries are logically distinguishable and mutually independent. By considering the bases upon which these questions should be resolved in any given case, the Comment will then conclude by atteinpting to frame a consistent and well-founded procedure which sufficiently defines the legal rights of the class and its representative following the disınissal of the representative's individual claims.

\section{Basic Elements of the Problem and How It Aruses}

In a normal two-party suit, the dismissal of one party terminates the proceeding. ${ }^{10}$ However, when a party represents or purports to represent a class of aggrieved persons similarly situated, some courts have found that the class aspect of the litigation may proceed even following the termination of the individual representative's cause of action. ${ }^{11}$ In such cases the court, in effect, finds that the class may yet achieve what the individual representative could not. ${ }^{12} \mathrm{~A}$ syllogistic analysis of this situation might cause one to conclude that such a court must have adopted a logically imconsistent position in per-

10. Fed. R. Civ. P. 12(b).

11. See cases cited note 69 infra. Rule 23 itself does not specify whether a class action may be dismissed by the court upon the ground that the representative's action has terminated, either because of mootness, separate adjudication, or other reason, prior to a final judgment concerning the class claims. The only requirement imposed upon the court concerning the dismissal of class actions appears in rule 23(e), which provides notice to the class of voluntary settleinents of the action:

A class action shall not be dismissed or compromised without the approval of the court, and notice of the proposed dismissal or compromise shall be given to all members of the class in such manner as the court directs. FED. R. CTV. P. 23(e).

See generally 3B MOORE $\llbracket$ 23.80[3]. For discussion of the applicability of rule 23(e) to dismissals which do not prejudice the rights of the class, see notes 96, 97 infra and accompanying text.

12. It has been said that the individual may not achieve through the class what he himself cannot achieve alone. See Mintz v. Mathers Fund, Inc., 463 F.2d 495, 499 (7th Cir. 1972); Croskey St. Concerned Citizens v. Romney, 459 F.2d 109, 113 (3d Cir. 1972) (Aldisert, J., concurring). But this statement focuses on the rights of the named plaintiff rather than on the rights of the class. The primary question in the cases here under consideration is not what the named plaintiff can or cannot achieve alone, but instead what the class is entitled to achieve once the named plaintiff's individual claim has been terminated either through separate adjudication or through mootness. See text accompanying notes 108-10 infra. 
mitting the class action to continue. If the named plamtiff is truly similarly situated with the class which he purports to represent, and if the named plaimtiff has lost his individual cause of action, then it would seem either to be the case that the remaining members of the class have similarly unsuccessful claims or else the first premise, that they are similarly situated with the plaintiff, is false. Likewise, if one contends that the named plaintiff is not similarly situated with the class which he purports to represent, then it would seein inescapable that he has neither the right nor the ability under rule 23 to mamtam an action on behalf of such a class.

Although this line of reasoning is based upon a justifiably felt necessity, which is imphicit in the requirements of rule $23,{ }^{13}$ for requiring typicality of the claims and defenses of the representative and for insisting on the fair and adequate representation of the class, the result which it reaches cannot be specifically supported or required by the actual language of the rule. Rule 23 says nothing of a need for the nained plaintiff to be "similarly situated," let alone "identically situated" with the rest of the class. ${ }^{14}$ Rather, the rule only requires that there be questions of law or fact "common to" the class, ${ }^{15}$ and that the named plaintiff's individual claim be "typical" of the claims or defenses of the class. ${ }^{10}$ The commonality requirement, however,

does not require that all the questions of law and fact raised by the dispute be common; nor does it establish any quantitative or qualitative test of commonality. All that can be divined from the rule itself is that the use of the plural "questions" suggests that more than one issue of law or fact must be common to members of the class. ${ }^{17}$

Indeed, one commentator has concluded that the typicality provision of the rule is wholly superfluous. ${ }^{18}$ Neither does the prerequisite of typicality rise to a demand that the class representative's claim be coextensive $^{19}$ or "typically successful" 20 with respect to those of the class. Fur-

13. Fed. R. Crv. P. 23(a)(2), (3), (4). See generally Hansberry v. Lee, 311 U.S. 32 (1940); Supreme Tribe of Ben-Hur v. Cauble, 255 U.S. 356 (1921); Smith v. Swormstedt, 57 U.S. (16 How.) 288 (1853); Alameda Oil Co. v. Ideal Basic Indus., Inc., 326 F. Supp. 98, 103 (D. Colo. 1971); Dolgow v. Anderson, 43 F.R.D. 472, 500 (E.D.N.Y. 1968); Northern Natural Gas Co. v. Grounds, 292 F. Supp. 619, 636 (D. Kan. 1968); 3B MOORE โI 23.02[1], at 23-74.

14. See Siegal v. Chicken Delight, Inc., 271 F. Supp. 722, 726-27 (N.D. Cal. 1967). See generally Donelan, supra note 2, at 527.

15. Fed. R. Crv. P. 23(a) (2).

16. Id. $23(\mathrm{a})(3)$. For further discussion of the typicality requirement, see notes 134-36 infra and accompanying text.

17. 7 WRIGHT \& MILLER $\$ 1763$, at 603-04 (footnotes omitted).

18. 3B MOORE $\{$ 23.06-1.

19. "To the extent that 'co-extensive' might suggest that the representatives' claims 
thermore, the rule does not require the named plaintiff himself to be "representative" of the class, but only that he be able to protect the interests of the absent class members fairly and adequately. ${ }^{21}$ Thus it appears to be possible for the requirements, precisely as expressed in the language of the rule, to be fulfilled despite the lack of the named plaintiff's continued stake in the outcome of the litigation.

This is not to say that any unaggrieved party may obtain a judicial forum merely by denominating his complaint a class action. It has recently been recognized that the problem of whether the class action should be allowed to continue and whether the individually unsuccessful named plaintiff should be allowed to continue to represent the class can only arise after the named plaintiff has asserted a justiciable personal claim against the defendant. ${ }^{22}$ Failure on the part of the rep-

must be substantially identical to those of the absent class members, it is too demanding a standard." 7 WRIGHT \& MILIER $\S 1764$, at 613. "Absolute identity is not required ...." Degnan, supra note 4 , at 716 (discussing CAL. R. Civ. P. 23, which has been applied in the same manner as the federal rule).

A number of courts have taken a relatively permissive approach to rule 23 (a)(3)'s requirement of typical claims or defenses and have permitted factual variations in the claims of the plaintiff class. See, e.g., Eisen v. Carlisle \& Jacquelin, 391 F.2d 555 (2d Cir. 1968); Fischer v. Weaver, 55 F.R.D. 454 (N.D. Ill. 1972); Iowa v. Union Asphalt \& Roadoils, Inc., 281 F. Supp. 391 (S.D. Iowa 1968).

20. For example, an employee alleging discrimination in the employment practices of his employer might well raise complaints that are typical of the class concerning allegations of lower pay, inferior working conditions, and longer promotion schedules for class members. But he still might be unable to recover on his individual claim because of the presence in his own employment record of excessive absences, frequent tardiness, poor production performance or other factors which would have providcd valid grounds for dismissal in his particular case. See, e.g., Huff v. N.D. Cass Co., 485 F.2d 710 (5th Cir. 1973); Cox v. Babcock \& Wilcox Co., 471 F.2d 13 (4th Cir. 1972); McAdory v. Scientific Research Instruments, Inc., 355 F. Supp. 468, 471-73 (D. Md. 1973). As another example, an insider may raise claims on behalf of himself which are typical of claims made by an entire class of stock purchasers, but still be prohibited froin personally recovering because of restrictions against insider trading under the Securities Exchange Act of 1934. See Mersay v. First Republic Corp., 43 F.R.D. 465 (S.D.N.Y. 1968). Therefore, individual claims need not be "typically successful" in order to be typical under 23(a)(3). See also Reed v. Arlington Hotel Co., 476 F.2d 721 (8th Cir.), cert. denied, 414 U.S. 854 (1973); Yaffe v. Powers, 454 F.2d 1362, 1366 n.2 (1st Cir. 1972); Miller v. Mackey Int'l, Inc., 452 F.2d 424 (5th Cir. 1971); Johnson v. Georgia Highway Express, Inc., 417 F.2d 1122 (5th Cir. 1969). See generally 7A WRIGHT \& MIILER § 1785, at 131-39; Advisory Committee's Notes to Rule 23, supra note 2, at 102-03.

21. FED. R. CIv. P. 23(a)(4). See generally Donelan, supra note 2, at 535; Ford, Federal Rule 23: $A$ Device for Aiding the Small Claimant, 10 B.C. IND. \& CoM. L. REV. 501, 509 (1969); Wright, supra note 2, at 172; Note, Class Actions: Defining the Typical and Representative Plaintiff Under Subsections (a)(3) and (4) of Federal Rule 23, 53 BosTon U.L. REV. 406 (1973).

22. See Kauffman v. Dreyfus Fund, Inc., 434 F.2d 727 (3d Cir. 1970), cert. denied, 401 U.S. 974 (1971), where the court said: 
resentative plaintiff to allege any real and immediate threatened or actual injury to himself at the outset of the action will cause both the individual and the class aspects of the complaint to be dismissed for failure to satisfy the "case or controversy" requirement of article III. ${ }^{23}$ This position was expressly endorsed by the Supreme Court in O'Shea $v$. Littleton, ${ }^{24}$ where the Court said: "[] $f$ none of the named plaintiffs purporting to represent a class establishes the requisites of a case or controversy with the defendants, none may seek relief on behalf of himself or any other meinber of the class." ${ }^{25}$ Accordingly, the problem of continuing class action status can only arise when, in addition to filing an action on behalf of the class, the representative has both asserted and lost a justiciable individual claim.

Such a loss may be occasioned by the factual inadequacy of the representative's individual claim or may rest upon legal grounds. Factual inadequacy is found when the representative's claim, though ade-

Before one may successfully institute a class action "[i]t is of course necessary generally that [he] be able to show injury to himself in order to entitle him to seek judicial rehief." . . In short, a predicate to [a named plaintiff's] right to represent a class is his eligibility to sue in his own right. Id. at 734 (citation omitted).

But cf. Vulcan Soc'y of N.Y. City Fire Dep't, Inc. v. Civil Serv. Comm'n, 490 F.2d 387 (2d Cir. 1973) (Friendly, J.), holding that a representative action could be inaintained by individual plaintiffs asserting a number of related claims, even though the individual plaintiffs were not personally affected by soine of the allegations. Id. at 399-400.

23. U.S. ConsT. art. III, \& 2. See generally Joint Anti-Fascist Refugee Comm. v. McGrath, 341 U.S. 123, 150 (1951); Aetna Life Ins. Co. v. Haworth, 300 U.S. 227, 240-41 (1937).

24. 42 U.S.L.W. 4139 (U.S. Jan. 15, 1974).

In $O$ 'Shea, the plaintiffs had brought a class action on behalf of the black citizens of Cairo, Illinois, alleging discriminatory and unconstitutional administration of criminal justice by city officials through the imposition of higher bonds, harsher sentences, and more expensive court fees upon black defendants in criminal cases. At the time the suit was filed, however, none of the nained representatives was himself either serving an allegedly illegal sentence or on trial or awaiting trial before the state inagistrate. $I d$. at 4140 . Having found no case or controversy, the Court made no determination concerning the maintainability of the class aspect of the action. It was suggested, however, that it may have been unmaintainable on the grounds of unmanageability as well. Id. at 4141 n.3.

25. Id. at 4141 . To create a case or controversy, the class advocate must do more than baldly assert a claim that such a controversy exists. See Watkins v. Chicago Housing Authority, 406 F.2d 1234, 1236-37 (7th Cir. 1969); Stephenson v. Stephenson, 249 F.2d 203, 208 (7th Cir. 1957). However, exactly how much he must claim and prove is not clearly defined. In some instances the court will at least require proof that other class meinbers exist who might be adversely affected by the alleged misconduct. See Bricker v. Crane, 468 F.2d 1228, 1232-33 (1st Cir. 1972). On other occasions the representative plaintiff has been required to allege and prove discrimination against at least one other meinber of the proposed class. Hadnott v. Laird, 463 F.2d 304 (D.C. Cir. 1972). 
quate on its face as stating a legally cognizable cause of action, is manifestly incapable of being proven. ${ }^{26}$ Legal grounds for dismissal, on the other hand, may exist in several forms. One of the legal grounds for the termination of the class representative's individual cause of action subsequent to filing is mootness. Mootness may arise from an unforeseen change in the personal situation of the representative which causes him to lose his claim involuntarily, ${ }^{27}$ or it inay result from voluntary action on his part. ${ }^{28}$ It may also result from a loss of standing to maintain his personal claim due to the defendant's acquiescence to the individual demands of the class representative. ${ }^{29}$ Other possible

26. See, e.g., Huff v. N.D. Cass Co., 485 F.2d 710 (5th Cir. 1973); Rothblum v. Board of Trustees, 474 F.2d 891 (3d Cir. 1973); Moss v. Lane Co., 471 F.2d 853 (4th Cir. 1973).

27. See, e.g., Wymelenberg v. Syman, 54 F.R.D. 198 (E.D. Wis. 1972). In Wymelenberg, the plaintiff brought a class action alleging that Wisconsin's divorce statute, which required a two-year period of in-state residency as a prerequisite to obtaining access to the state court, was unconstitutional. After filing the individual and class complaints but prior to the certification of the class, the plaintiff's wife died. The court held that the plaintiff's involuntary removal from the class of married persons subject to the statutory provision did not destroy the right of the other members of the class to have the action concluded on their behalf. The court did not reach the question of whether the plaintiff would adequately represent the class interests, since, due to the nature of the claim, no facts were in dispute, and it promptly held the statute unconstitutional. Id. at 199.

28. See, e.g., Palmer v. National Cash Register Co., 346 F. Supp. 1043 (S.D. Ohio 1972); Fogg v. New Eng. Tel. \& Tel. Co., 346 F. Supp. 645 (D.N.H. 1972); Vaughan v. Bower, 313 F. Supp. 37 (D. Ariz.), affd, 400 U.S. 884 (1970); Rackley v. Board of Trustees, 238 F. Supp. 512 (E.D.S.C. 1965). On most occasions of this sort, the plaintiff has cooperated with conciliatory offers by the defendant and so, technically speaking, both parties have voluntarily acted to the derogation of the plaintiff's personal cause of action.

29. See, e.g., Hines v. City Fin. Co., 474 F.2d 430 (D.C. Cir. 1972); Rivera v. Freeman, 469 F.2d 1159 (9th Cir. 1972); Jenkins v. Umited Gas Corp., 400 F.2d 28 (5th Cir. 1968); Cypress v. Newport News Gen. \& Nonsectarian Hosp. Ass'n, 375 F.2d 648 (4th Cir. 1967); Gatling v. Butler, 52 F.R.D. 389 (D. Conn. 1971) (all holding such acquiescence not to justify dismissal). Contra, Heumann v. Board of Educ., 320 F. Supp. 623 (S.D.N.Y. 1970). To allow the defendant to successfully moot a class action by self-initiated acquiescence with the named plaintiff's individual demands might encourage the defendant to avoid class litigation by picking off class representatives one at a time. This would contravene the basic policy of class action practice which is to avoid a multiplicity of suits. See Bledsoe, Mootness and Standing in Class Actions, 1 FLA. Sr. U.L. REv. 430 (1973).

A defendant may, however, seek to moot a class action by complying generally with the asserted demands of the entire class. See, e.g., Gray v. Board of Trustees, 342 U.S. 517 (1952); Caplin v. Oak, 356 F. Supp. 1250 (S.D.N.Y. 1973); Lopez v. White Plains Housing Authority, 355 F. Supp. 1016 (S.D.N.Y. 1972). If the court views such acquiescence as a disingenuous attempt by the defendant to forestall litigation without putting to rest the underlying controversy in the case, however, the court may permit the class action to proceed. See, e.g., MoGuire v. Roebuck, 347 F. Supp. 1111 (E.D. Tex. 1972); Vaughan v. Bower, 313 F. Supp. 37 (D. Ariz), affd, 400 U.S. 884 (1970). 
legal grounds for dismissal of the representative's personal claim include its settlement by arbitration ${ }^{30}$ or application of the doctrine of res judicata due to the claim's accelerated adjudication, either in the same forum ${ }^{31}$ or in another court, ${ }^{32}$ prior to the adjudication of the pending class controversy. While these two categories of ways in which the class representative can lose his claim may serve as general reference points, the line between legal grounds for dismissal and the factual inadequacy of the representative's claim is not free froin ambiguity. Factual findings must support legal determinations of inootness, standing, and res judicata; and legal rules are essential for estimating the factual adequacy of the representative's personal arguments. ${ }^{33}$ Thus, any class-representative plaintiff whose personal cause of action founders because of legal or evidentiary deficiencies may find his class-imitiated suit in an uncertain legal posture.

The Supreme Court has not yet taken a position as to the proper status of either the class action or the class representative following the loss to the representative of his personal cause of action subsequent to his filing of a class action along with a justiciable personal claim. Indeed, when the Court confronted this question in Indiana Employment Security Division v. Burney, ${ }^{84}$ it refused to decide it. In Burney, the named plaintiff filed a class action alleging that the Indiana system of administering unemployment insurance conflicted with section 303(a)(1) of the Social Security Act. ${ }^{35}$ The basis for this charge was that the state of Indiana had suspended the named plaintiff's unemployment benefits without a prior administrative hearing. After the plaintiff filed the action, she was granted such a hearing to determine whether her benefits had been wrongfully terminated. Nevertheless,

30. See Hutchings v. United States Indus., Inc., 428 F.2d 303 (5th Cir. 1970).

31. See, e.g., Smith v. Delta Air Lines, Inc., 486 F.2d 512 (5th Cir. 1973); Huff v. N.D. Cass Co., 485 F.2d 710 (5th Cir. 1973); Moss v. Lane Co., 471 F.2d 853 (4th Cir. 1973); Cox v. Babcock \& Wilcox Co., 471 F.2d 13 (4th Cir. 1972).

32. See, e.g., Spriggs v. Wilson, 467 F.2d 382 (D.C. Cir. 1972); Watkins v. Chicago Housing Authority, 406 F.2d 1234 (7th Cir. 1969).

33. An interesting case from the Seventh Circuit presents the problem as it approaches this borderline situation. In Mintz v. Mathers Fund, Inc., 463 F.2d 495 (7th Cir. 1972), the plaintiff in a stockholders' derivative action held 15 shares of the defendant corporation's stock. At trial it was discovered that the shareholder could not prove his ownership for the time periods relevant to the alleged offenses. Since ownership was the sole legal ground for the plaintiff's interest in the action, the class complaint was dismissed. Id. at 498-99.

34. 409 U.S. 540 (1973) (per curiam).

35. 42 U.S.C. $\$ 503(a)(1)$ (1970), which provides that the Secretary of Labor shall not certify for payment any state unless he finds that such state's laws provide for administrative inethods which are "reasonably calculated to insure full payinent of unemployment coinpensation when due." 
prior to a final resolution of the administrative proceedings, the threejudge court below granted summary judgment to the plaintiff and her class. $^{36}$ In a per curiam decision, the Supreme Court vacated the decision of the lower court and remanded the case for a determination of mootness. ${ }^{37}$ While this disposition of the case might seem to imply that the Supreme Court would allow a defendant to moot a class action by voluntarily acceding to the named plaintiff's individual demands, this issue was not directly before the court in the Burney case. Furthermore, the opinion is short and it provides little guidance for determining when an action may be mooted as to a class of unnamed persons who still are likely to remain aggrieved subsequent to the mootness of their representative's claim. Nor does it indicate any criteria that can be applied to the original representative of such a class which, if met, would permit that action to continue under his leadership.

When similar situations have been presented to other courts, the responses have been ad hoc and inconsistent. ${ }^{38}$ Thus, a coherent analytical approach has yet to be developed for resolving these issues. As a result, there are no generally accepted guidelines on which decisions can be based. The remaining portion of this Comment, therefore, shall first look nore closely at the lower court cases which have dealt with this issue and then shall conclude by proposing such a method of analysis.

\section{Current Judictal Treatment}

The solution to the problem concerning the continued legal status of the class action and the class representative following the loss to the representative of his imdividual cause of action hinges on the answer to

36. Hiatt v. Indiana Employment Security Div., 347 F. Supp. 218 (N.D. Ind. 1971). The defendants then appealed the decision directly to the Supreme Court under 28 U.S.C. \& 1253 (1970).

37. 409 U.S. at 542. As in O'Shea, there was a strong dissent by Justice Douglas, who argued that since the plaintiff had not received from the defendant the precise relief sought, and since dismissal would allow the defendant to create a "litigious merry-go-round," the court should have affirmed the summary judgment for the plaintiff and her class. Id. at 544 .

38. Compare Huff v. N.D. Cass Co., 485 F.2d 710 (5th Cir. 1973) with Rothblum v. Board of Trustees, 474 F.2d 891 (3d Cir. 1973). In both cases the named plaintiff's individual claim was subjected to a preliminary hearing on its merits and was found wanting before the trial court had consented to entertain certification of the class action; but where the Fifth Circuit found the resultant dismissal of the action to be in error, the Third Circuit sustained. Contradictory results on practically identical facts also were reached in Gatling v. Butler, 52 F.R.D. 389 (D. Conn. 1971) (allowing the class aspect of the litigation to continue), and Wojcik v. Noren, 349 F. Supp. 1286 (D. Conn. 1972) (disallowing the class action). 
one basic question: what relationship, if any, exists between the termination of the named representative's individual stake in the litigation and the capacity of the class to continue as a valid independent entity before the court? In inost instances, opinion writers have adopted one of two views concerning the relationship between the dismissal of the representative's cause of action and the continued inaintainability of the class action. ${ }^{39}$ The first view asserts that the dismissal of the named plaintiff necessitates the coinplete termination of the class action. The second view rejects the validity of the first and holds that once the named plaintiff has properly pleaded a class action, the loss of his individual cause of action generally has no effect either on the continued maintainability of the class action or on the propriety of his continuing to serve as the representative of the class. Two distinct lines of cases corresponding to these views have developed among the federal courts.

First Approach: Stake in the Outcome as a Necessary Condition for Maintaining Class Action Status

The origin of this first line of cases arises out of dicta in two early decisions by the Eighth Circuit Court of Appeals and the United States Supreme Court. These cases suggested that a named plaintiff cannot maintain a class action unless he has a personal stake in its outcome. In the first of these cases, City of Kansas City v. Williams, ${ }^{40}$ the Eighth Circuit, having found that the nained plaintiffs had adequately proven personal ijjury, nevertheless commented:

It is of course necessary generally that a plaintiff be able to show injury to himself in order to entitle him to seek judicial relief. He cannot be a mere volunteer and ask judicial intervention simply "because someone else may be hurt," but he "Inust present facts sufficient to show that his individual need requires the remedy for which lie asks." $" 41$

In somewhat the saine context, the Supreme Court stated in Bailey $v$. Patterson $^{42}$ that plaintiffs "cannot represent a class of whoin they

39. Compare notes 44,69 infra.

40. 205 F.2d 47 (8th Cir.), cert. denied, 346 U.S. 826 (1953). The actual holding of this case is that where class action treatment does not serve some useful purpose, for example in preventing a multiplicity of suits, the action will be denied class action status. Here the imdividual plaintiff won his individual law suit but failed to offer proof that other blacks had been denied access to public swimming facilities as he had been.

41. Id. at 51 (citations omitted).

42. 369 U.S. 31 (1962). This case held in part that a plaintiff may represent a class only with respect to those allegations which the plaintiff has personal standing to assert. The question is therefore left entirely open whether a plaintiff who loses 
are not a part."43 These cases did not go so far as to adopt the view that if a named plaintiff loses his personal cause of action subsequent to filing a class action, the class action must be dismissed. But, perhaps due to a somewhat indiscriminate reliance on the language from these two frequently cited opinions, a number of courts appear subsequently to have adopted this even stronger position. ${ }^{44}$

For example, in Spriggs $v$. Wilson, ${ }^{45}$ a case in which the named plaintiff's individual cause of action was mooted subsequent to filing but prior to certification under rule 23(c)(1), the Court of Appeals for the District of Columbia Circuit asserted that "[s]ince the case is moot as to the [naned plaintiff] it cannot be maintained as a class action." 46 In a similar procedural context, the Seventh Circuit likewise asserted in Watkins $v$. Chicago Housing Authority"7 that "[t] class action becaine moot when the Authority cancelled the eviction

his standing to sue after having had standing to file the action should be precluded from continuing his action as a class action.

43. Id. at 32-33. Despite the holding in Bailey, several cases have held that an association may be allowed to sue as a representative of its members in a class action so long as the association is active and consists of a closely related nnembership, and where it would actively pursue its members' interests. See, e.g., Arkansas Educ. Ass'n v. Board of Educ., 446 F.2d 763 (8th Cir. 1971); Sinith v. Board of Educ., 365 F.2d 770 (8th Cir. 1966). These cases depart from the strict rule in Bailey in that the associations are not strictly inembers of the classes which they seek to represent.

44. Each of the following cases can be cited in support of the proposition that if a plaintiff loses his personal cause of action after filing a class action or if he is adjudged on evidentiary grounds not to be an aggrieved member of the class which he purports to represent, then that plaintiff cannot represent the class action, which therefore must be dismissed. See, e.g., Hall v. Beals, 396 U.S. 45 (1969); Barr v. United States, 478 F.2d 1152 (10th Cir.), cert. denied, 414 U.S. 910 (1973); Rothblum v. Board of Trustees, 474 F.2d 891 (3d Cir. 1973); Long v. District of Columbia, 469 F.2d 927 (D.C. Cir. 1972); Spriggs v. Wilson, 467 F.2d 382 (D.C. Cir. 1972); Heard v. Mueller Co., 464 F.2d 190 (6th Cir. 1972); Mintz v. Mathers Fund, Inc., 463 F.2d 495 (7th Cir. 1972); Norman v. Connecticut State Bd. of Parole, 458 F.2d 497 (2d Cir. 1972); Davis v. Ichord, 442 F.2d 1207 (D.C. Cir. 1970); Cash v. Swifton Land Corp., 434 F.2d 569 (6th Cir. 1970); Watkins v. Chicago Housing Authority, 406 F.2d 1234 (7th Cir. 1969); Geehring v. Municipal Court, 357 F. Supp. 79 (N.D. Ohio 1973); Lopez v. White Plams Housing Authority, 355 F. Supp. 1016 (S.D.N.Y. 1972); DiJulio v. Digicon, Inc., 339 F. Supp. 1284 (D. Md. 1972); City of Philadelphia v. American Oil Co., 53 F.R.D. 45 (D.N.J. 1971); Callier v. Hill, 326 F. Supp. 69 (W.D. Mo. 1970); Craddock v. Hill, 324 F. Supp. 183 (W.D. Mo. 1970); Heumann v. Board of Educ., 320 F. Supp. 623 (S.D.N.Y. 1970); Burney v. North Am. Rockwell Corp., 302 F. Supp. 86 (C.D. Cal. 1969).

45. 467 F.2d 382 (D.C. Cir. 1972).

46. Id. at 385. Certification of a class action constitutes the judicial recognition that the action is maintainable as a class action. FEd. R. CIv. P. 23(c)(1). For a further discussion of the significance of certification, see notes 64, 67-68 infra and accompanying text.

47. 406 F.2d 1234 (7th Cir. 1969). 
proceedings and restored the [representative] plaintiffs to their original status . . . ." In another case, Norman v. Connecticut State Board of Parole, ${ }^{49}$ the class action had proceeded to both certification and final adjudication before the named plaintiff's cause of action became moot during the pendency of the defendant's appeal. Due to the mootness of the representative's claim, the Court of Appeals for the Second Circuit instructed the lower court to dismiss the action without prejudice, saying: "Since it is clear that a nanned plaintiff cannot bring a suit for a class of which he is not a part ... we remand the case to the district court with directions to dismiss without prejudice on grounds of inadequacy of representation . . . ."50

Several justifications have been offered for adherence to this strict procedure. First, the courts adhering to this approach are justifiably concerned that once a nained plaintiff has lost his personal cause of action, the prerequisites of the related class action can no longer be sustained under rule 23 . It has been argued that since the representative is no longer a neinber of the class, he lacks the representativeness required by rule 23(a)(4) to continue to inaintain a suit on behalf of of the rest of the class. ${ }^{51}$ Moreover, grave apprehensions have been ex-

48. Id. at 1237.

49. 458 F.2d 497 (2d Cir. 1972).

50. Id. at 499. The Second Circuit instructed the trial court to retain the case on its docket for $\mathbf{3 0}$ days before finally dismissing it in order to allow another representative to come forth on belialf of the class. In light of the circumstances of this case, however, this fact does not materially distinguish the approach in Norman froin the approach in Watkins or Spriggs. This is because there was little, if any, likelihood that another suitable representative would appear within the prescribed 30 day period. In the first place, it was not certain that there would exist another person within 30 days of the Second Circuit's ruling who could fit the description of a class menbera prisoner appearing without counsel before the Connecticut State Board of Parole in a parole revocation liearing. Indeed, the Board of Parole could liave prevented anyone from becoining a class meinber either by delaying such a hearing, by allowing counsel to such person without clianging the Board's overall policy of not allowing counsel in parole revocation hearings, by refusing to institute proceedings to revoke the parolee's parole in the particular case, or by attempting to have the charges against the parolee which jeopardized his parole dropped. Moreover, even if another parolee became so situated that he would liave been an adequate class representative, there is no indication tbat the court was to provide notice to such person of the pending class action. Finally, even if such a parolee was found and was notified of the pending action, it is not certain that he would consent to represent the class. Thus, because of the extreine unlikelihood of another class meinber appearing before the court within 30 days to represent the class, the action by the Second Circuit in Norman was tantamount to a dismissal of the class action solely because of the mootness of the individual plaintiff's claim.

51. For example, see the language in the Norman case, quoted in the text accoinpanying note 50 supra, where the Second Circuit explicitly based its dismissal of the class action "on grounds of inadequacy of representation." See also Heard v. Mueller 
pressed that proceeding beyond the point of the representative's dismissal would leave no concrete adversity in the case to sharpen the presentation of issues. ${ }^{52}$ Therefore, it is argued, to allow such an action to continue would violate the case or controversy requirement of article III, section 2 of the Constitution, ${ }^{53}$ and would engage the court in the unauthorized solicitation of actions ${ }^{54}$ and the rendering of advisory opinions. ${ }^{55}$

Nevertheless, these arguments are not completely persuasive. By viewing the dismissal of the named representative as leading directly to the dismissal of the class action, the courts have overlooked a number of important considerations. As has already been observed, the specific wording of rule 23(a)(4) only requires that the representative "fairly and adequately protect" the interests of the class. ${ }^{50}$ It is not self-evident that a dismissed representative plaintiff cannot do this, especially when his own dismissal was involuntary or due to legal technicalities. ${ }^{57}$ There may indeed be situations in which the named representative unquestionably would continue to represent the class interests adequately despite the termination of his personal claim. ${ }^{58}$ For example, it is often the case, especially when a class action has been

Co., 464 F.2d 190 (6th Cir. 1972). But see Huff v. N.D. Cass Co., 485 F.2d 710, 714 (5th Cir. 1973):

[Plaintiff] should not be found to be disqualified solely by an advance determination that his claim is predictably not a winning claim and that, therefore, he cannot adequately represent the class as mandated by $23(\mathrm{a})(4)$.

See generally 7 WRIGHT \& MILLER \& 1761.

52. See Watkins v. Chicago Housing Authority, 406 F.2d 1234, 1237 (7th Cir. 1969); Heumann v. Board of Educ., 320 F. Supp. 623 (S.D.N.Y. 1970); cf. O'Shea v. Littleton, 42 U.S.L.W. 4139 (U.S. Jan. 15, 1974).

53. Heumann v. Board of Educ., 320 F. Supp. 623, 624 (S.D.N.Y 1970).

54. It can be argued that once all grievances between the actual parties before the court have been disposed of, further judicial cognizance of a controversy in any form between such parties is unwarranted. See Elias v. National Car Rental Sys., Inc., 59 F.R.D. 276 (D. Minn. 1973), where, in response to a suggestion by the dismissed named plaintiff that the court should retain jurisdiction over the class action and seek another representative on its behalf, the court held that to issue notice of a class action's pendency following the originally named plaintiff's refusal to prosecute the action would be "in a sense merely soliciting a client for plaintiff's counsel . ..." Id. at 277.

55. Id. See also O'Shea v. Littleton, 42 U.S.L.W. 4139 (U.S. Jan. 15, 1974).

56. See notes 13-21 supra and accompanying text.

57. Some cases have recognized that a representative plaintiff who has lost his individual cause of action can continue to adequately represent the class interests. See, e.g., Huff v. N.D. Cass Co., 485 F.2d 710 (5th Cir. 1973); Wymelenberg v. Syman, 54 F.R.D. 198 (E.D. Wis. 1972). But see Mintz v. Mathers Fund, Inc., 463 F.2d 495 (7th Cir. 1972); Geehring v. Municipal Court, 357 F. Supp. 79 (N.D. Ohio 1973). For a further discussion of this issue, see notes 122-53 infra and accompanying text.

58. See La Sala v. American Sav. \& Loan Ass'n, 5 Cal. 3d 864, 871-72, 489 P.2d 1113, 1117, 97 Cal. Rptr. 849, 853 (1971). See note 59 infra. 
brought for injunctive or declaratory relief, that a dismissed representative will retain close ties to the remaining class members and remain strongly committed to vindicating the riglits of the rest of the class. ${ }^{69}$ Additionally, it may sometimes occur that no other class member would be available to represent the class. ${ }^{60}$ Surely, where such circumstances exist, allowing a dismissed representative who would continue to provide adequate representation for the class to remain as the class representative would, in some cases, ${ }^{61}$ be preferable to dismissing the class action entirely and leaving the grievances of the class without judicial consideration or redress. ${ }^{62}$

59. Suits for injunctive relief nay be brouglit under any of the categories of rule 23 (b), but they fall primarily under $23(\mathrm{~b})(2)$. Such actions are especially adapted to class coinplaints alleging violations of civil and constitutional rights, see generally $7 \mathrm{~A}$ WRIGHT \& MILLER $\$ 1776$, and they encompass an area of the law in which the concepts of the "private attorney general" and the "ideological plaintiff" are already familiar. See, e.g., Hutchings v. United States Indus., Inc., 428 F.2d 303, 310 (5th Cir. 1970); Jenkins v. United Gas Corp., 400 F.2d 28, 32 (5th Cir. 1968); Fogg v. New Eng. Tel. \& Tel. Co., 346 F. Supp. 645 (D.N.H. 1972); Bowe v. Colgate-Palmolive Co., 272 F. Supp. 332 (S.D. Ind. 1967), modified, 416 F.2d 711 (7th Cir. 1969). See also Newman v. Piggie Park Enterprises, Inc., 390 U.S. 400, 401-02 (1968); Jaffe, The Citizen as Litigant in Public Actions: The Non-Hohfeldian or Ideological Plaintiff, 116 U. PA. L. ReV. 1033 (1968). In a 23(b)(2) action, it may often be the case that the named plaintiff continues to fcel a part of the aggrieved class and maintains a strong personal interest in its welfare so that even though lis individual cause of action may be barred by some interceding event, defense, or ruling, he could still provide adequate representation for the class.

Actions brought under 23 (b) (3), on the other hand, are usually aggregations of individual claims which seek monetary relief for past injuries. See generally 7A WRIGHT \& MIILED \$ 1784; Miller, Problems in Administering Judicial Relief in Class Actions Under Federal Rule 23(b)(3), 54 F.R.D. 501 (1972); Comment, Rule 23: Categories of Subsection (b), 10 B.C. IND. \& CoM. L. REv. 539, 542-47 (1969). A representative who possesses no monetary stake in the outcome of such a class action, where the primary inotivation for proceeding is financial, would probably have less incentive to undergo the labor of providing adequate representation for the class than would a representative who lias a pecuniary interest in the result.

60. It may often be the case that no other class inembers are readily identifiable to the court. See, e.g., Rivera v. Freeman, 469 F.2d 1159 (9th Cir. 1972); Norman v. Connecticut State Bd. of Parole, 458 F.2d 497 (2d Cir. 1972); Wyinelenberg v. Syman, 54 F.R.D. 198 (E.D. Wis. 1972). In other situations, other class members may be easily identified, but they may be reluctant to conne forward for fear of reprisals by the defendant or those closely allied with him. This is sometimes the case in class actions brouglit by an einployee against his employer, where, rightly or wrongly, the other employees may fear that if they were to step forward to represent the class they would lose their jobs. See Parliam v. Southwestern Bell Tel. Co., 433 F.2d 421 (8th Cir. 1970).

61. The sorts of cases in which such a disposition would be appropriate are discussed in notes 111-21 infra and accompanying text. In certain cases, Judge Friendly suggests that allowing the representative to continue to represent the class will even work to the convenience of the defendant. Vulcan Soc'y of N.Y. City Fire Dep't, Inc. v. Civil Serv. Comm'n, 490 F.2d 387, 400 (2đ Cir. 1973).

62. Outright dismissal at a late stage is especially onerous when it abrogates the 
The view that the dismissal of the representative plaintiff's individual cause of action necessitates the dismissal of the class action is especially untenable with respect to class actions which have proceeded beyond certification under rule $23(\mathrm{c})(1) .^{03}$ When a class action has received certification, it obtains an independent legal existence before the court. ${ }^{04}$ Once this has occurred, there is no reason to

rights of those who had relied upon the adjudication of their personal claims in the class action and who might otherwise have pursued an action on their own behalf, but are now barred from doing so by the running of a statute of limitations. Cf. Philadelphia Elec. Co. v. Anaconda Am. Brass Co., 42 F.R.D. 324 (E.D. Pa. 1967), modified, 47 F.R.D. 587 (E.D. Pa. 1969). Dismissal at a late stage also becones critical in Title VII actions where, following a dismissal of the named plaintiff, the judicial forum usually does not once again become available to the class until a new representative has, like the dismissed plaintiff, gone through the lengthy process of exhausting all available administrative remedies. See Oatis v. Crown Zellerbach Corp., 398 F.2d 496 (5th Cir. 1968). See also Callier v. Hill, 326 F. Supp. 669, 673 (W.D. Mo. 1970). Moreover, dismissal of the class aspect of any case at a late stage in the litigation may, in effect, require the class to relitigate in a later proceeding issues which had already been fully litigated. This would result in an imefficient duplication of effort and would place an unnecessary burden upon already limited judicial resources, in addition to possibly placing severe strain on the financial resources of the elass or its representatives. For these reasons, a heavy burden should rest upon the defendant to prove the impropriety of the class action when the named plaintiff is to be dismissed at a late stage in the proceedings.

Prior to the 23(c)(1) determination regarding maintainability, however, the burden of establishing the right to invoke class action status is clearly placed upon the plaintiffs. See Danner v. Phillips Petroleum Co., 447 F.2d 159, 164 (5th Cir. 1971); Cash v. Swifton Land Corp., 434 F.2d 569, 571 (6th Cir. 1970); Demarco v. Edens, 390 F.2d 836, 845 (2d Cir. 1968); McAdory v. Scientific Research Instruments, Inc., 355 F. Supp. 468, 473 (D. Md. 1973). See generally 3B MOORE T 23-02[2]; 7 WRIGHT \& MLLER $\S 1765$, at 626 . Therefore, there is less reason to be reluctant to dismiss the class action due to the loss by the named plaintiff of his individual cause of action subsequent to filing but before certification. Sce also notes 98-102 infra and accompanying text.

63. See note 64 infra and text accompanying note 109 infra.

64. Since a class action is only presumed to exist for limited purposes on the basis of the pleadings prior to certification, see note 100 infra, the class action cannot be thought to exist before the court in a technical sense until that time. If certification is denied under rule $23(\mathrm{c})(1)$, no significance can be subsequently attached to the fact that the action was once denominated as a class action. Where certification is denied, the action is "stripped of its character as a class action." Advisory Committee's Note to Rule 23, supra note 2, at 104. But cf. Philadelphia Elec. Co. v. Anaconda Am. Brass Co., 43 F.R.D. 452, 461 (E.D. Pa. 1968), modified, 47 F.R.D. 587 (E.D. Pa. 1969):

That the class aspect of the litigation is separate from the personal action of the individual plaintiff is indicated by the fact that, at certification, the court makes a separate judicial determination that, in addition to the class representative, an aggrieved class exists before it which complies with the requirements of rule 23; without such a finding, the action cannot proceed as a class action. Weisman v. MCA, Inc., 45 F.R.D. 258, 261 (D. Del. 1968); 7 Wright \& MILLER $\$ 1760$, at 579. Furthermore, at certification the class itself becomes entitled to a number of protective safeguards 
require the legal rights of the class to hinge on the success of the individual claim of the class representative. Concrete adversity may persist despite the loss to the representative of his own cause of action because the aggrieved class remains before the court due to the recognition of the class cause of action. An additional reason for not dismissing the class action in these circumstances results from the fact that the basic idea of a class action involves an extension of the concept of joinder of parties, since the class action form of proceeding is used in lieu of the joinder of the class meinbers. ${ }^{65}$ Much as it would be improper to dismiss all the parties who had been joined in an action under rules 19 or 20 simply because there was need to dismiss one of thein, ${ }^{66}$ so it would seem improper to dismiss the claims of an entire class simply because of the need to dismiss one of its inembers.

In addition, the court has the power following certification to subdivide the class and reclassify the issues as necessary to insure the adequate representation and proper protection of the interests of the

which were not previously available to it. See note $105 \mathrm{infra}$. Indeed, it would not be misleading to say that the class has been joined as a separate party to the action, since the class action device is an outgrowth of the practice of permissive joinder, see note 65 infra, and since disinissal of the class aspect of the litigation leaves the representative's right to continue with his personal action unimpaired. See Lumbermens Mut. Cas. Co. v. Rhodes, 403 F.2d 2, 5-6 (10th Cir. 1968), cert. denied, 394 U.S. 965 (1969); Kronenberg v. Hotel Governor Clinton, Inc., 41 F.R.D. 42, 45 (S.D.N.Y. 1966).

65. See FED. R. CIv. P. 23(a)(1) which permits the maintenance of class actions when, inter alia, "the class is so numerous that joinder of all meinbers is impracticable ...." Historically, "[t]he class action was both an escape froin and an adjustment to the rule of joinder," since compulsory joinder would otherwise bar actions entirely where joinder of all parties would be impossible. 3B MOORE $\pi$ 23:02[1], at 23-72.

The kinship between class actions under $23(\mathrm{~b})(2)$ and (b) (3) and joinder procedure is further reflected in the similarity of the criteria for joinder of parties and for maintenance of an action as a class action. Rule 20(a)'s prerequisite for permissive joinder of parties that "any question of law or fact common to all [the joined parties] ... arise in the action," closely parallels rule 23(a)(2)'s requirement that there be "questions of law or fact common to the class" in a class action under rule 23.

Actions under $23(\mathrm{~b})(1)$ parallel the procedure of mandatory joinder under rule 19. See 7A WRIGHT \& MIILER $\S 1772$, at 4 . The reseinblance is logical and not accidental. See Kaplan, Continuing Work of the Civil Committee: 1966 Amendments of the Federal Rules of Civil Procedure (I), 81 HARv. L. Rev. 356, 389 (1967).

66. See FeD. R. Crv. P. 20(a), which provides in part:

A plaintiff or defendant need not be interested in obtaining or defending against all the relief deinanded. Judgment may be given for one or more of the plaintiffs according to their respective rights to rehef . . . .

Thus, in cases where parties are joined for the sake of convenience and efficiency to both the court and the parties, it is not contemplated that the substantive rights of the joined parties should rise or fall together. See generally 7 WRIGHT \& MnLER § 1652. "[E]ach plaintiff's right of action remains distinct, as if it had been brought separately." Id. at 266-67. 
class. ${ }^{67}$ Therefore, if the court were to find that the dismissed representative would inadequately represent the class, it is within the power of the court to order the substitution of another representative or the subdivision and realignment of the class or its issues under the best available representation. In all class actions certified under 23 (c) (1), this procedure would seem preferable to a dismissal of the entire class action upon a finding that the named plamtiff could no longer be an adequate class representative simply because of the failure or mootness of his personal cause of action. ${ }^{68}$

\section{Second Approach: Stake in the Outcome as Unnecessary for Maintaining Class Action Status}

The second line of cases has adopted the view that, subsequent to filing a class action, the loss to the named plaintiff of his personal cause of action should generally have no effect upon either the continued mamtamability of the class action or the ability of the named plaintiff to continue to represent the class. ${ }^{69}$ It reasons that if the action

67. FED. R. Civ. P. 23(c)(4) provides: "When appropriate (A) an action may be brought or maintained as a class action with respect to particular issues, or (B) a class may be divided into subclasses ...." FED. R. Crv. P. 23(d) further provides: "In the conduct of actions to which this rule applies, the court may make appropriate orders . . . for the protection of the members of the class or otherwise for the fair conduct of the action . . . ." See White v. Sullivan, 474 F.2d 16 (5th Cir. 1973); 7 WRIGHT \& MILLER $\$ 1765$, at 623-25.

68. Since the court has the responsibitity and the power to issue orders for the protection of the interests of the class members under rule 23(d), see note 67 supra, the court should not dismiss an otherwise maintainable class action until a reasonable time has been allowed for the replacement of the representative parties. See Cox v. Babcock \& Wilcox Co., 471 F.2d 13 (4th Cir. 1972); 7 WRIGHT \& MIILER \& 1759, at 576-77; cf. Smith v. Board of Educ., 365 F.2d 770 (8th Cir. 1966). Further support for this contention may be found in the language of rule 17 which provides that "[n]o action shall be dismissed on the ground that it is not prosecuted in the name of the real party in interest until a reasonable time has been allowed after objection for ratification of commencement of the action by, or joinder or substitution of, the real party in interest ..." FED. R. Crv. P. 17(a). Thus, it might be argued that if a plaintiff has inadvertently lost his nembership in the class and injustice would result from a flat dismissal of the action, then in one sense the plaintiff is simply not a real party in interest and under the requirements of rule 17 an opportunity for joinder or substitution of a real party should be provided. See 6 WRIGHT \& MILLER $\$ 1555$, at 704-07.

69. The ratio decidendi of all the following cases is the same: The mere fact that a named plaintiff has lost his personal cause of action after filing a justiciable claim in conjunction with a class action is no reason to bar that plaintiff from continuing to pursue the class cause of action; therefore, notwithstanding such a loss by the named plaintiff, the class action must be allowed to continue normally. See, e.g., Roberts v. Union Co., 487 F.2d 387 (6th Cir. 1973); Francis v. Allied Serv. Co., 486 F.2d 597 (5th Cir. 1973); Smith v. Delta Air Lines, Inc., 486 F.2d 512 (5th Cir. 1973); Martin v. Thoinpson Tractor Co., 486 F.2d 510 (5th Cir. 1973); Huff v. N.D. Cass Co., 485 F.2d 710 (5th Cir. 1973); Moss v. Lane Co., 471 F.2d 853 (4th Cir. 1973); Cox v. Babcock \& Wilcox Co., 471 F.2d 13 (4th Cir. 1972); Rivera v. Freeman, 469 F.2d 
has been properly pleaded, ${ }^{\mathbf{7 0}}$ the representative can proceed to represent the class to the same extent he otherwise could have if no individual dismissal had occurred. The opinion in Moss v. Lane Co. ${ }^{71}$ illustrates this approach:

If the plaintiff were a member of the class at the commencement of the action and his competency as a representative of the class [were] then determined or assumed, the subsequent dismissal or mootness of his individual claim, particularly in a discrimination case, will not operate as a dismissal or render moot the action of the class, or destroy the plaintiff's right to litigate the issues on behalf of the class. ${ }^{72}$

A similar result was reached by the Fifth Circuit Court of Appeals in Huff v. N.D. Cass Co. ${ }^{73}$ In an en banc reversal of its earlier decision in the case, ${ }^{74}$ the Fifth Circuit held in Huff that a class action plaintiff who had alleged unfair employment practices by his employer could not be excluded from representing the class simply because the court below had found, prior to certification, that the named plaintiff's individual claim was without inerit. ${ }^{75}$ The court of appeals did require on remand that the trial court continue to consider the validity of the

1159 (9th Cir. 1972); Brown v. Gaston County Dyeing Mach. Co., 457 F.2d 1377 (4th Cir.), cert. denied, 409 U.S. 982 (1972); Jenkins v. United Gas Corp., 400 F.2d 28 (5th Cir. 1968); Wymelenberg v. Syman, 54 F.R.D. 198 (E.D. Wis. 1972); McGuire v. Roebuck, 347 F. Supp. 1111 (E.D. Tex. 1972); Fogg v. New Eng. Tel. \& Tel. Co., 346 F. Supp. 645 (D.N.H. 1972); Gatling v. Butler, 52 F.R.D. 389 (D. Conn. 1971); Vaughan v. Bower, 313 F. Supp. 37 (D. Ariz.) (three judge court), affd, 400 U.S. 884 (1970); Rackley v. Board of Trustees, 238 F. Supp. 512 (D.S.C. 1965); MaSwain v. Board of Educ., 138 F. Supp. 570 (E.D. Tenn. 1956); cf. Hines v. City Fin. Co., 474 F.2d 430 (D.C. Cir. 1972); Palmer v. National Cash Register Co., 346 F. Supp. 1043 (S.D. Ohio 1972). See also Cypress v. Newport News Gen. \& Nonsectarian Hosp. Ass'n, 375 F.2d 648 (4th Cir. 1967).

70. The previous analysis required no such presupposition, since under it the entire action is to be terminated upon disinissal of the named plaintiff's personal claim regardless of whether the action was properly pleaded or not.

71. 471 F.2d 853 (4th Cir. 1973).

72. Id. at 855 (einphasis added).

73. 485 F.2d 710 (5th Cir. 1973).

74. Huff v. N.D. Cass Co., 468 F.2d 172 (5th Cir. 1972), criticized in 5 RuTGersCAMden L.J. 414 (1973). The reversal, however, did not come before the earlier circuit decision had been followed by the Sixth Circuit in Heard v. Mueller Co., 464 F.2d 190, 194 (6th Cir. 1972). Recently, the Sixth Circuit has reversed its holdiug in Heard and now is in accord with the secoud Huff decision. Roberts v. Union Co., 487 F.2d 397 (6th Cir. 1973).

75. "As to the right of Huff to maintain the class action, this court is committed to the principle that the standard for determining whether a plaintiff may maintain a class action is not whether he will ultimately prevail on his claim." 485 F.2d at 712 . Accord, Brown v. Gaston County Dyeing Mach. Co., 457 F.2d 1377 (4th Cir.), cert. denied, 409 U.S. 982 (1972). Contra, White v. Gates Rubber Co., 53 F.R.D. 412 (D. Colo. 1971); Newman v. Avco Corp., 313 F. Supp. 1069 (D. Tenn.), rev'd on other grounds, 453 F.2d 743 (6th Cir. 1970). 
class action as it had been initially pleaded. As a part of its ensuing 23(c)(1) certification hearing on the maintainability of the class action, the trial court was directed especially to consider the plaintiff's continuing "nexus" with the class in order to allow him to continue representing it following certification. ${ }^{70}$ Therefore, it may be inferred from the court's opinion that the class action may continue and that the named plaintiff may serve as class representative in the action, although the court would only allow him to do so as long as that "nexus" endures. On the other hand, the absence of this "nexus" would, under this view, justify the dismissal of the individual plaintiff and in all probability the class action as well. ${ }^{77}$

To the extent that these cases may be interpreted as generally creating a right in the plaintiff to continue representing the class despite his loss of a personal cause of action, ${ }^{78}$ this view is too simplistic. Such an interpretation of class action procedure overlooks the conditional nature of the plaintiff's right to bring and maintain a class action. Indeed, the portion of rule 23(a) which enables individuals to sue on behalf of a class is written im permissive rather than mandatory language $;^{79}$ the language of the rule itself does not appear to require that an action continue to be treated as a class action by the courts in every case where the requirements of the rule were satisfied at some previous time. Even after the court has certified that a class action is maintainable, it may alter or amend that certification before any decision on the merits has been reached; or it may require the intervention of other plaintiffs in order to serve the interests of the class or to assure the unequivocal presentation of issues in controversy. ${ }^{80}$ Accordingly, a representative plaintiff has no absolute right to represent the class. Therefore, it cannot be asserted categorically that the cessation of a named plaintiff's individual cause of action has no effect on the maintainability of the class action or on his representative status. Moreover, it may also be the case that at certain early stages in the litigation the termination of the plaintiff's personal cause of action may properly terminate his right to pursue the class action further. ${ }^{41}$

76. 485 F.2d at 714.

77. Id.

78. This is the clear import of the court's language in Moss v. Lane Co., 471 F.2d 853, 855 (4th Cir. 1973). See text accompanying note 72 supra.

79. FED. R. CIV. P. 23(a) reads: "One or more members of a class may sue or be sued as representative parties on behalf of all . . " (emphasis added). Likewise, subsection 23(b) begins, "An action may be maintained as a class action if . . " (emphasis added).

80. FED. R. Civ. P. 23(c) (1), (d) (4).

81. See notes 22-29, 52-55 supra, 98-102 infra and accompanying text. 
A corollary to the views presented in Moss and Huff concerning the extent of the rights of named plaintiffs to represent class actions is the assertion that the plaintiff class itself has a right to be represented which should be unaffected by the disposition of the class representative's claim prior to certification. It has been thought that once a class action has been properly constituted at the time of filing, it acquires a right to receive a judicial hearing which survives the dismissal of the named representative's personal claim. ${ }^{82}$ This supposition resenbles the contention that since class actions are to be presumed valid prior to certification, ${ }^{83}$ all class actions must proceed to a $23(\mathrm{c})(1)$ determination. ${ }^{84}$ Both of these positions would seem to be untenable.

One argument supporting the notion of a mandatory 23(c)(1) hearing rests on the claim that the language of rule 23(c)(1) itself is mandatory. Based upon the fact that the rule states "[a]s soon as practicable after the commencement of an action brought as a class action, the court shall determine by order whether it is to be so maintamed,"85 this argument reasons that the courts must make a 23(c)(1) determination in every action brought as a class action. ${ }^{86}$ However, the language of the rule is not wholly unconditional. It qualifiedly' states that the determination must be made only "[a]s soon as practicable." ${ }^{\prime 87}$ Arguably, it may be impracticable in some cases for the court to undertake a 23(c)(1) determination following the loss to the named representative of his individual cause of action, and in those cases no such determination can be required. For example, when the plaintiff, having lost his personal claim, no longer desires to litigate his prior allegation of a class complaint, it may be impracticable for the court to instigate a 23 (c)(1) hearing when no other

82. See La Sala v. American Sav. \& Loan Ass'n, 5 Cal. 3d 864, 870, 489 P.2d 1113, 1116, 97 Cal. Rptr. 849, 852 (1971), which holds that a discharged class representative continues to have a fiduciary duty to the class to vindicate its rights in a judicial hearing. See also Bledsoe, supra note 29 , at 461 , who states:

[A]n outright dismissal of the entire class action or a negative ruling on a

23 (c) (1) determination because of the representative's lack of standing is not justifiable when the class has constitutional standing with respect to the challenged conduct.

83. The notion of presumptive validity results from the principle that prior to certification of the action as a maintainable class action under FED. R. CIv. P. 23(c)(1), the suit should be treated as a class action for purposes of dismissal or compromise. See Gaddis v. Wyman, 304 F. Supp. 713 (S.D.N.Y. 1969); Philadclphia Elec. Co. v. Anaconda Am. Brass Co., 42 F.R.D. 324 (E.D. Pa. 1967), modified, 47 F.R.D. 587 (E.D. Pa. 1969). See also notes 89-97 infra and accompanying text.

84. See 3B MOORE I 23.50; Bledsoe, supra note 29, at 446-48.

85. FED. R. CTV. P. 23 (c) (1) (emphasis added).

86. See 3B MOORE II 23.50[1].

87. Fed. R. Crv. P. 23(c)(1). 
representative has presented himself to the court on behalf of the class and when the membership of the class itself is as yet unknown. Thus, it may be argued that the language of rule 23(c)(1) does mandate a formal determination of class action status, but only in those cases where such a determination is practicable. This argument is not irrefutable, since it can be argued in response that the "practicability" requirement of rule $23(\mathrm{c})(1)$ refers only to the time when the determination is to be made, and not also to the feasibility of making such a determination, but it does tend to refute the argument that the language of the rule conclusively mandates a 23(c)(1) hearing in every case. ${ }^{88}$

Further undermining such a claim is the fact that there is little authority to support the general notion that every alleged class is entitled to a 23(c)(1) determination. The lone case which has been cited by the commentators for this purpose, Philadelphia Electric Co. v. Anaconda American Brass Co. ${ }^{89}$ only substantiates this position in certain situations. ${ }^{90}$ In Philadelphia Electric the named plaintiffs filed a class action suit alleging antitrust violations by the defendants. Prior to certification, the plaintiffs and several of the defendants agreed upon a private settlement which effectively would have bound the class, since during the pendency of the action the statute of limitations had tolled. ${ }^{91}$ The court held that before the settlement could be approved under rule 23 (e), notice had to be given to the class members of the proposed settlement of the action and of their right to intervene. Accordingly, prior to certification the court assumed that the class action existed, but only in a limited sense. The court stated that the action "must be assumed to be class action for purposes of dismissal or compromise under 23(e) unless and until a contrary determination is made under 23(c)(1)." ${ }^{22}$ Thus it was the plaintiff's attempt to coinpromise the claims of the class which led the court to decide to provide notice to the absent class members in spite of the fact that no 23 (c) (1) determination

88. Cf. Gillibeau v. City of Richmond, 417 F.2d 426, 432 (9th Cir. 1969); Berman v. Narragansett Racing Ass'n, 48 F.R.D. 333, 336 (D.R.I. 1969). See also 7A WRIGHT \& MILLER $\$ 1785$, at 130-31; Frankel, Some Preliminary Observations Concerning Civil Rule 23, 43 F.R.D. 39 (1967).

89. 42 F.R.D. 324 (E.D. Pa. 1967).

90. See 3B MOORE Tf 23.50, at 23-1103 nn.12, 13; Bledsoe, supra note 29, cf. Philadelphia Housing Authority v. American Radiator \& Standard Sanitary Corp., 323 F. Supp. 364, 373 (E.D. Pa. 1970), modified sub nom. Ace Heating \& Plumbing Co. v. Crane Co., 453 F.2d 30 (3d Cir. 1971).

91. 42 F.R.D. 324, 325-26 (E.D. Pa. 1967). See generally Comment, Class Actions Under New Rule 23 and Federal Statutes of Limitation: A Study of Conflicting Rationale, 13 VIIL. L. Rev. 370 (1968).

92. 42 F.R.D. at 326 (emphasis added). 
had yet formally established the existence of a maintainable class action. ${ }^{.3}$

Philadelphia Electric cannot be read to support the requirement of a 23(c)(1) hearing in every case. ${ }^{94}$ The court expressly limited its language so as to presume the validity of the class action only for restricted purposes..$^{95}$ The only reason a 23(c)(1) determination occurred im this case was that considerations of due process required notice to be given to members of the class under rule 23(e) because they would be bound by the consequences of the settlement. ${ }^{96}$ These due process considerations are absent where the dismissal of the action would not foreclose the class from seeking further relief. ${ }^{97}$ Therefore,

93. Id.

94. See Philadelphia Housing Authority v. American Radiator \& Standard Sanitary Co., 323 F. Supp. 364, 373-74 (E.D. Pa. 1970), modified sub nom. Ace Heating \& Plumbing Co. v. Crane Co., 453 F.2d 30 (3d Cir. 1971), where the court interpreted Philadelphia Electric to pertain only to the due process requirement of notice to members of a potential class.

95. See note 92 supra and accompanying text. In another opinion arising out of the sanie case, the court further limited the language of Philadelphia Electric. Philadelphia Elec. Co. v. Anaconda Am. Brass Co., 43 F.R.D. 452 (E.D. Pa. 1968), modificd, 47 F.R.D. 557 (E.D. Pa. 1969). According to this case there inust be an affirmative determination of maintainability by the court in order to relate the later validity of the class action back to the time of filing of the action. Id. at 460 . Thus, the validity of a class action during the period between filing and certification is strictly conditioned upon a retroactive 23(c)(1) determination of maintainability. The holding of the earlier Philadelphia Electric case, requiring notice of a voluntary disımissal arisiug out of a settlement between the parties, therefore cannot be construed to create a presumption of the substantive existence of a class action itself requiring that the action proceed to certification in all cases. It is one thing to afford a potential class cause of action the protection of certain present procedural safeguards, but it is quite another to attempt to justify a claim of the actual existence of a cognizable class cause of action between filing and certification simply on the basis of certain safeguards afforded the asserted class because of the possible future finding that such an action exists. Thus, a notion of presumptive validity cannot be used to vahidate the very existence of a class cause of action prior to certification such as one must justify in order to entertain a class action independent of any continuing private causes of action before the court.

96. The court stated: "Under these circumstances, it is imperative that no final result be achieved as to auy party without notice to those potentially affected thereby." 42 F.R.D. at 328. See also Mullane v. Central Hanover Bank \& Trust Co., 339 U.S. 306 (1950); Hansberry v. Lee, 311 U.S. 32 (1940); Philadelphia Housing Authority v. American Radiator \& Standard Sanitary Corp., 323 F. Supp. 364, 373-74 (E.D. Pa. 1970), modified sub nom. Ace Heating \& Plumbing Co. v. Crane Co., 453 F.2d 30 (3d Cir. 1971).

Moreover, the court indicated that its 23(c)(1) certification could be justified by due process concepts, "even in the absence of Rule 23(e)." 42 F.R.D. at 327.

97. Sce Spriggs v. Wilson, 467 F.2d 382, 385-86 (D.C. Cir. 1972); Polakoff v. Delaware Steeplechase \& Race Ass'n, 264 F. Supp. 915, 917 (D. Del. 1966).

It is generally understood that rule 23 (e) applies only to voluntary dismissals by the plaiutiff, and not to dismissals by the court either for lack of jurisdiction or because 
a 23(c)(1) determination would not be an essential exercise in those situations.

Both the assertion that the plaintiff's rights to a 23 (c)(1) determination are unconditional and the related view that an action in favor of the class may, merely on the basis of the pleadings, be presumed to exist prior to the certification of that action are deficient. As was observed above, ${ }^{98}$ for the court to continue the proceeding on behalf of an unrecognized class of plaintiffs beyond the named plaintiff's loss of his individual cause of action usually would violate the case or controversy requirement of article III of the Constitution. ${ }^{99}$ During the period between filing and certification, a class action is supported solely by the pleadings, which may or may not have a foundation in fact compatible with the requirements of rule 23(a) and (b). Since the class has not yet been found to exist by the court, it is merely thought or assumed to exist hypothetically for the limited purpose of enabling the plaintiff to prove its actual existence. ${ }^{100}$ If, subsequent to filing the action, the plaintiff's cause of action is lost, there is no longer any actual party before the court with a claim against the defendant. The representative no longer has a claim, and the class, since it has not yet been actually recognized, cannot yet support an action before the court. Indeed, the posture of the action at this point is not significantly different from that in $O$ 'Shea $v$. Littleton, ${ }^{101}$ where the presence of a presently unaggrieved representative seeking to vindicate the rights of an allegedly aggrieved, but unrecognized class, was held distinctly to be violative of the case or controversy requirement. In either case it

of non-compliance with the requirements of rule 23 , or after a decision on the merits. See 3B MOORE \ा 23.80[3], at 23-1507; 7A WRIGHT \& MILler $\$ 1797$, at 235-36.

98. See text accompanying notes 22-25, 52-55 supra.

99. U.S. ConsT. art. III, \& 2. See Heumann v. Board of Educ., 320 F. Supp. 623, 624 (S.D.N.Y. 1970): "In the absence of any showing of continuing or potential harm to this plaintiff . . . further prolongation of the action would violate the "case or controversy" requirement of Article III . . . ."But see McGuire v. Roebuck, 347 F. Supp. 1111, 1114 (E.D. Tex. 1972):

The doctrine of mootness is tied to the concern that once a plaintiff loses his right to relief the court, im effect, will be rendering an advisory opinion if it continues since no actual controversy is before it. But this reasoning does not apply in the class action context, because the fact that some members of the class no longer are subject to the alleged discrimination does not destroy the existence of a controversy between defendant and the remaining class members.

100. See Moss v. Lane Co., 471 F.2d 853, 855 (4th Cir. 1973). Prior to certification, the class is only a denominated or putative class rather than an independent entity before the court. See Spriggs v. Wilson, 467 F.2d 382, 385 (D.C. Cir. 1972); Lopez v. White Plains Housing Authority, 355 F. Supp. 1016 (S.D.N.Y. 1972).

101. 42 U.S.L.W. 4139 (U.S. Jan. 15, 1974). See notes 24, 25 supra and accompanying text. 
would be an act of judicial overreaching and solicitation to assert or retain jurisdiction over a class action which an unaggrieved party seeks to champion. ${ }^{102}$ Accordingly, if a class representative loses his personal cause of action prior to the entry of a court order of certification, the court would appear to be barred by the holding in O'Shea from further entertaining the class action.

In sum, neither the approach represented by the Spriggs, Watkins, and Norman line of cases, ${ }^{103}$ which too readily rejects the individually unsuccessful named plaintiff as a continuing representative of the class, nor the opposite approach used by the Huff and Moss line, ${ }^{104}$ which allows the continuing representation by such a party even in the absence of a certified class, is wholly satisfactory for dealing with the problem created by the class representative's loss of his individual cause of action after a related justiciable class action has also been filed.

\section{The CASe for a Bifurcated Approach}

Both of the approaches encountered above operate on the premise that the question concerning the continuation of class action status following the representative's dismissal can be answered in a single proposition of one sort or another. The first line of cases found that the dismissal of the named representative logically entails the dismissal of the entire action. The second view held that the maintainability of class actions must be determined without regard to the subsequent dismissal of the named representative by looking to whether the action was inaintainable as a class action at the time of filing and, in some cases, by considering further the representative's continuing "nexus" with the class. The various difficulties encountered by both of these approaches can be avoided by dividing the judicial inquiry into two distinct and unrelated questions. First, at the time when the plaintiff lost his personal interest in the class, had a legally recognized class action come into existence? And second, if one had, who should henceforth represent it?

One indication that the continued maintainability of a class action and its proper representation are logically separable issues is the fact that as the litigation advances the class becomes entitled to specified protective safeguards and acquires certain rights which are independent of the posture of the class representative. ${ }^{105}$ In order to know the im-

102. See notes 53-55 supra and accompanying text.

103. See notes 45-50 supra and accompanying text.

104. See notes 69-77 supra and accompanying text.

105. FED. R. Crv. P. 23(d)(2). Members of a class certified under 23(c)(1) have 
pact which a plaintiff's dismissal will have upon a given class action, it may therefore be necessary to know the status of that action at the time of the dismissal. If the class action has been certified by the court, then the hurdle of nonjusticiability following dismissal of the representative's claim can be overcome by asserting the separate legal existence of the class before the court wholly independent of the representative plaintiff. ${ }^{106}$ On the other hand, the question of who should continue to represent that class must be answered through a consideration of the representative's continuing ability fairly and concretely to present and pursue the action of the absent class members. This is a question which is separate from the question whether a valid class action continues to exist. ${ }^{107}$ Thus, in practice, it should not be enough to show that the individual plaintiff no longer has a cause of action in his personal capacity in order to justify dismissing the class action. Nor should it suffice to assert the continuing maintainability of the class action in order to justify allowing the original plaintiff to continue to represent it. Further consideration of the criteria involved in determining the existence of a recognizable class action and the adequacy of representation is necessary in order to develop an analytical frainework for dealing consistently with these problems.

\section{When is a Class Action Recognizable As Such?}

To answer the question whether the class action itself should be allowed to proceed despite the loss by the class representative of his individual cause of action, one must first answer the question: when has a class become a class? This question must be asked with respect to to three time periods: (1) when the plaintiff loses his individual right to sue before the filing of the class action, (2) when the loss occurs between the filing of the action and the order certifying the action as a class action, and (3) after certification. Written opinions concerning dismissals falling in the first and last time periods appear less frequently than those which concern dismissals occurring in the second, the latter being considerably harder to deal with.

the right to be protected generally as the court deems necessary. This right includes, but is not limited to, notice advising class members of their right to present mdividual damage claims, notice of proposed modifications in the action, and the opportunity to express disapproval of the representation of the class, or to intervene in the action personally. See generally 7A WRIGHT \& MIILER $\$ 1793$.

106. See note 64 supra.

107. These conclusions are supported by the fact that parties plaintiff may generally intervene in, exchange representative roles in, or sever connections with a class action and still leave that particular action in progress. See generally Fed. R. Crv. P. 23(d). 
On the one extreme, if a plaintiff has lost the ability to allege personal injury prior to filing the class' action, it is clear that he cannot bring a justiciable cause of action either on behalf of himself or his class. ${ }^{108}$ Therefore, the problem of continuing class action status following the discovery of such a loss should not arise at all. Likewise on the other end of the procedural scale, when the plaintiff's dismissal occurs following a 23(c)(1) decree, this development should not affect the continued existence of the class action. Here the class action has been judicially determined to be inaintainable, and an aggrieved class apart from the representative has been found to exist. ${ }^{109}$ Thus, the only problem confronting the court in this situation is securing adequate representation for the action. Concerning the interim time period between the filing and the certification of the action, it has already been argued that to continue to entertain a class action once the representative plaintiff has lost his individual cause of action would violate the case or controversy requirement of article III. ${ }^{110}$ The action is not justiciable and the court may not assert jurisdiction over it. It follows then that the issuance of a 23(c)(1) certification provides a primary line of demarcation between those actions which can continue to exist after the dismissal of the individual representative and those which cannot.

In certain exceptional circumstances, however, it can persuasively be contended that class actions which have not yet been found maintainable under 23(c)(1) at the time of the dismissal of the representative's cause of action should nevertheless be found to be recognizable and thereby be permitted to continue.

The first exception recognizes that there may be situations in which, if the class action were to be dismissed prior to certification due to the mootness of the class representative's claim, it would be unlikely that the claim of the class ever could be adjudicated. ${ }^{111}$ This would

108. O'Shea v. Littleton, 42 U.S.L.W. 4139 (U.S. Jan. 15, 1974). See notes 24, 25 supra and accompanying text.

109. See note 64 supra and accompanying text.

110. See notes $22-25,52-55,98-102$ supra and accompanying text.

111. Such possibilities are inherent in cases presenting the type of factual situation which existed in Rivera v. Freeman, 469 F.2d 1159 (9th Cir. 1972). In Rivera, the class representative sought to challenge on behalf of herself and all others similarly situated the constitutionality of a statute which allowed the detention of juveniles for up to 72 hours without a judicial hearing. It is clear that the state could successfully avoid any challenge to this statute by promptly releasing any detainee who sought to assert in a class action the unconstitutionality of this statute. Once the detainee had been released, the relief which he had personally sought would have been obtained, and his canse of action would become moot. If the mootness of each representative's 
be the case if the defendant were to attempt to avoid class litigation by mooting the claim of any class representative who files a class action against him without mooting the claim with respect to the rest of the class. ${ }^{112}$ If the courts were willing to dismiss class actions as a result of such tactics, the defendant could successfully preclude the class from ever receiving an adjudication of its case on the merits by defeating seriatim each representative's cause of action. ${ }^{113}$ In order to avoid this sort of evasion of justice, the courts should depart from a strict adherence to the case and controversy requirement and permit the class action to continue whenever it appears that the class action as pleaded would continue to assert a redressable claim under adequate representation.

In the second type of exceptional case, when the plaintiff's individual claim is defeated during a period of undue and avoidable judicial delay in certifying the class action, the harm to the aggrieved class caused by the resultant dismissal of the class action ${ }^{114}$ may be remedied by determining the maintainability of the class action based on the facts as they existed at the time the determination should have been made. ${ }^{115}$ While it has never been specified how extensive the precertification hearings ought to be, rule 23 (c) (1) requires that certification issue "as soon as practicable after the commencement of [the] action."116 Therefore, if the court has caused extensive prehminary

cause of action could be held to be grounds for dismissal of the class action, every class action brought by such plaintiffs could be automatically dismissed.

112. See note 29 supra.

113. See, e.g., La Sala v. American Sav. \& Loan Ass'n, 5 Cal. 3d 864, 873, 489

P.2d 1113, 1118, 97 Cal. Rptr. 849, 854 (1971) where the court states:

If other borrowers bring a class action, [defendant] may again waive as to those representative borrowers, and agam move to dismiss the action. Such a procedure could be followed ad infinitum for each successive group of representative plaintiffs. If defendant is permitted to succeed with such revolving door tactics, only members of the class who can afford to initiate or join litigation will obtain redress; rehef for even a portion of the class would compel innumerable appearances by imdividual plaintiffs. Yet the function of the class action is to avoid the imposition of such burdens upon the class and upon the court.

114. See note 62 supra.

115. Somewhat similar treatment of a class action has been advocated where certification has been unavoidably delayed. It has been argued that in this situation the action should be treated as if it had already been certified, at least for purposes of dismissal or compromise, until the court can make its decision concerning the maintainability of the class action. 7A WRIGHT \& MrLLER $\$ 1785$, at 130-31. The most bikely reason for this recommended treatment is to protect the putative class by requiring notice to potential class members of attempts to dismiss or compromise the class action in a way which would jeopardize the rights of the class members to seek further relief against the defendant in the future. See notes 96,97 supra and accompanying text.

116. Fed. R. Civ. P. 23(e)(1). See notes 85-88 supra and accompanying text. This has been interpreted to mean "the earliest pragmatically wise moment." Berman v. Narragansett Racing Ass'n, 48 F.R.D. 333, 336 (D.R.I. 1969). 
hearings to be conducted to probe into the merits of the individual plaintiff's cause of action before reaching a 23(c)(1) determination, ${ }^{117}$ or if there is undue delay for other reasons, the grounds may be laid for legally recognizing the class action retroactively to the time when inaintainability should have been determined. ${ }^{118}$

A possible third exception could arise when the action as filed constitutes a "perforce"119 class action. Certain types of actions may be class actions by their very nature due to the fact that the character of the defendant's conduct necessarily affects a certain class as a class. ${ }^{120}$ It may therefore be possible to recognize those actions as constituting class actions at law from the point of their inception, for whenever an action is a class action of necessity, it will always be "practicable" to certify the action as soon as it is filed. ${ }^{121}$

117. Huff v. N.D. Cass Co., 485 F.2d 710 (5th Cir. 1973); Moss v. Lane, 471 F.2d 853 (4th Cir. 1973); Brown v. Gaston County Dyeing Mach. Co., 457 F.2d 1377 (4th Cir.), cert. denied, 409 U.S. 982 (1972).

118. This exception would have provided alternative grounds for the results reached in Huff and Moss, see notes 71-77 supra and accoinpanying text, since in such cases the lower court had refused to certify the class action until after the plaintiff's individual cause of action had been thoroughly examined to see whether it was likely to succeed.

119. See Jenkins v. United Gas Corp., 400 F.2d 28, 33 (5th Cir. 1968); Callier v. Hill, 326 F. Supp. 669, 673 (W.D. Mo. 1970).

120. For example, discrimination based upon racial or ethnic classifications as well as most other forms of discrimination by definition imply discrinnination against a group of persons as a group; see Hall v. Werthan Bag Co., 251 F. Supp. 184, 186 (M.D. Tenn. 1966). Sinilarly, abuse of political power logically entails the abuse of the rights of some political body. Not all actions, however, brought as class actions would be perforce class actions. For exainple, the construction of a highway does not necessarily entail offending the rights of citizens, even though on some occasions highway construction may deprive an identifiable class of people of certain rights to an undefiled environment. See Nolop v. Volpe, 333 F. Supp. 1364 (D.S.D. 1971).

Under this conceptualization, a perforce class action was explicitly recognized as such in Jenkins v. United Gas Corp., 400 F.2d 28 (5th Cir. 1968), but not in Callier v. Hill, 326 F. Supp. 669 (W.D. Mo. 1970). See also Johnson v. Georgia Highway Express, Inc., 417 F.2d 1122 (5th Cir. 1969); Hall v. Werthan Bag Corp., 251 F. Supp. 184 (M.D. Tenn. 1966).

The suggestion has also been made that certain aspects of the substantive law liave come to embrace class concepts and that the substantive law now recognizes class causes of action where offenses against the public have occurred through various abuses of collective powers. Exainples of such offenses have been cited in both the antitrust and consumer protection areas. See Hazard, The Effect of the Class Action Device upon the Substantive Law, 58 F.R.D. 307 (1973). Such class actions could also be designated as perforce class actions.

121. This exception would permit the result in several cases, predominantly Title VII actions, which have allowed a class action to continue, despite the dismissal of the named plaintiff's personal action, by proceeding on the grounds that the class per se has a legal cause of action. See, e.g., Reed v. Arlington Hotel Co., 476 F.2d 721 (8th Cir.), cert. denied, 414 U.S. 854 (1973); Fogg v. New Eng. Tel. \& Tel. Co., 346 F. Supp. 645 (D.N.H. 1972). 
To summarize, a class is not a class until it has been recognized in fact or is recognizable at law. Thus, an alleged class action should not be allowed to continue following the dismissal of its named representative unless the class action has either been certified under 23(c)(1) or one of these three types of exceptional circumstances is present.

\section{The Ability of a Discharged Representative to Continue Representing the Class Action}

Independent of the question whether the class action can contimue is the question of who should represent it. Many legal concepts have figured into analyses of this question, but none of them has proved to be particularly satisfactory. One of the most baffling aspects of the problem is the fact that the rule does not clearly define the standards by which the named representative's capacity and right to represent the class should be determined. ${ }^{122}$

According to the analysis presented in this Comment, the question of whether a named plaintiff may continue to represent a class following the loss of his own cause of action can only arise under two circumstances: when his dismissal follows the certification of a class

122. There has been some controversy concerning the time at which the representative must be deemed to have been adequate in order to allow him to serve as class representative. Some courts mdicate that if the plaintiff was an adequate representative at the time of filing, then subsequent developments will not diminish his ability to represent the class. See Gatling v. Butler, 52 F.R.D. 389, 395 (D. Conn. 1971): "Gatling must be deemed to have been a proper representative of the class from the time suit was initiated." Accord, Moss v. Lane Co., 471 F.2d 853, 855 (4th Cir. 1973); cf. Hines v. City Fin. Co., 474 F.2d 430, 433 n.6 (D.C. Cir. 1972). Others have required that the plaintiff must be an adequate representative at the time of certification, and that dismissal prior to certification weighs conclusively against his representativeness. See Watkins v. Chicago Housing Authority, 406 F.2d 1234, 1236-37 (7th Cir. 1969): "It must be a novel theory . . . that nained plamtiffs without the right to further represent themselves can continue to represent unnained parties allegedly in a similar situation .... [Because of] the changed status of the named plaintiffs ... this contention is devoid of merit." Cf. Spriggs v. Wilson, 467 F.2d 382, 385 (D.C. Cir. 1972).

Neither approach is a satisfactory one, however, in that events may occur subsequent to filing and subsequent to certification which may affect the ability of the representative to represent the class interests adequately. See Sol S. Turnoff Drug Distribs., Inc. v. N.V. Nederlandsche Combinatie Voor Chennische Industrie, 51 F.R.D. 227 (E.D. Pa. 1970). Thus, although membership in the class at the time of filing would seem to be a minimal requirement of adequate representation, see Fitzgerald v. Kriss, 10 F.R.D. 51, 55 (N.D.N.Y. 1950); 7 WRIGHT \& MIILER $\$ 1761$, no single point should be designated as the sole time when the representative's capacity to represent the class should be determined. Instead, the courts should constantly reevaluate the named plaintiff's representative status in light of all events which occur during the cause of action. 
action ${ }^{123}$ or when it precedes certification but the action is allowed to continue, because under one of the three exceptions dismissal of the named plaintiff's cause of action prior to certification does not also entail dismissal of the class aspect of the action. ${ }^{124}$ Under these circumstances, adequacy of representation remains as a distinct issue for the court to consider independent of the question of whether the class action should be allowed to continue. ${ }^{125}$ In so domg, the court may either adjudge the adequacy of the plaintiff's representativeness from a direct examination of all the facts and circumstances of the particular case, ${ }^{126}$ or it may attempt to utilize certain other legal concepts as touchstones of adequate representation. Three such concepts have been used most commonly as indicia of adequate representation, namely, class nnembership, standing, and typicality. However, none of these criteria can be supported by the plain language of the rule as being necessary for a nained plaintiff to be an adequate representative. Further, it is submitted that such concepts are simply mappropriate for resolving the question of adequacy of representation as it arises in these contexts.

Membership in the Class. Rule 23 states that "[0]ne or more members of a class may sue or be sued as representative parties on behalf of all . . . ."127 Therefore, it has been stated that membership in the class is a required characteristic of the class representative. ${ }^{128}$ The caveat has thus been implied that dismissal of the individual plaintiff's claim operates to terminate mennbership in the class and, by the same token, the capacity to sue on its behalf. Based upon this reasoning, the Supreme Court in Hall v. Beals ${ }^{129}$ held that plaintiffs who had not personally suffered under the state residency laws whose constitutionahty they sought to challenge in a class action could not represent the class of voters who had. Recent authority, however, has rejected the dictum that current or continuing inembership in the class is a required trait of the class representative under rule 23 , so long as the named plaintiff held a defimable membership in the class ho seeks

123. See text accompanying notes $98-102$ supra.

124. See text accompanying notes 111-21 supra.

125. See notes 63-68 supra and accompanying text.

126. See notes $145-53$ infra and accompanying text.

127. FeD. R. CIV. P. 23(a). See generally 7 WRIGHT \& MIIIER $\$ 1761$.

128. See, e.g., Bailey v. Patterson, 369 U.S. 31 (1962); Chatman v. Barnes, 357 F. Supp. 9 (N.D. Okla. 1973). See generally McCabe v. Atchison, Topeka \& Santa Fe Ry., 235 U.S. 151 (1914).

129. 396 U.S. 45 (1969). See also O'Shea v. Littleton, 42 U.S.L.W. 4139 (U.S.

Jan. 15, 1974). 
to represent at the time the action was filed..$^{130}$ Hall $v$. Beals, it is argued, does not contradict this position since the plaintiff in that case was never a member of the class. ${ }^{131}$ Therefore, it cannot be cited for the proposition that a plaintiff cannot represent a class if he was once a part of that class.

Rule 23(a) lists four prerequisites to a class action. ${ }^{132}$ It does not indicate that "ineinbership" in the class per se should be treated as a fifth prerequisite to the class action. Indeed, it does not even define what is ineant by class "membership." The apparent reason for this is that, prior to a final decision on the merits of the case, membership in the class is strictly a factual inatter which can only be determined with reference to the definition of the class as drafted and proposed by the plaintiff himself. Actual legal membership in the class cannot specifically be determined until judgment is entered in the action brought as a class action, since it is at that time that the court determines who is entitled to share in the relief obtained by the representative. $^{133}$ Therefore, lack of membership in the class cannot be used as a mearingful index for ascertaining the ability of a dismissed representative to serve as a named party to a continuing class action.

Typicality. Although it is clear that an individual plaintiff may be no longer "similarly situated" with the class after the termination of his personal cause of action, this does not also necessarily imply that such a plaintiff has failed to raise claims typical of those of the class under rule 23(a)(3) and that he may therefore no longer represent the action on behalf of the class. ${ }^{134}$ In deciding whether the personal claims which the plaintiff has raised are "typical claims," one should

130. See Vaughan v. Bower, 313 F. Supp. 37, 40 (D. Ariz.), aff d, 400 U.S. 884 (1970).

131. The Court in Hall had stated, "The [plaintiffs] "cannot represent a class of [which] they are not a part' . . . a class of which [they] have never been members." 396 U.S. at 49 (citation omitted).

132. See note 5 supra.

133. See generally 3B MOORE $\llbracket$ 23.01[11.-3], at 23-33.

134. The claim of atypicality has been raised against an unsuccessful named plaintiff to defeat his continuing representation when he no longer could be considered similarly situated with the class because he had received full satisfaction of his personal claims, without corresponding satisfaction of the class grievances. See Geehring v. Municipal Court, 357 F. Supp. 79 (N.D. Ohio 1973); Callier v. Hill, 326 F. Supp. 669 (W.D. Mo. 1970). Being "similarly situated," however, is not a specific requirement of rule 23, see note 14 supra and accompanying text. And even if it were to be considered an implied prerequisite of class action status, the fact that one is no longer similarly situated with the class does not entail the conclusion that he was never so situated. Thus, the question is left whether he has been thereby sufficiently "similarly situated" in order to qualify as an adequate representative of the continuing class action. 
not look predominately to the validity of those allegations or to the likelihood that the representative will be successful in proving them, but primarily to their substance. ${ }^{135}$ If the allegations of the representative are fundamentally those which the inembers of the class themselves would raise, then the prerequisite of rule 23(a)(3) would appear to be fully satisfied regardless of whether the representative's personal claim is subsequently lost. Therefore, the provision requiring the existence of typical claims in the action also would not tend to subvert the ability of a representative who has lost his personal cause of action to adequately protect or promote those claims on behalf of the class. ${ }^{138}$

Standing. Some cases have relied heavily upon a finding of a plaintiff's lack of continued standing with respect to his personal claim as a justification for finding that he has become an inadequate representative of the class and that he is therefore no longer capable of maintaining the class action. ${ }^{137}$ Thus, the Third Circuit has ruled that a "plaintiff who is unable to secure standing for himself is certainly not in a position to 'fairly insure the adequate representation' of those alleged to be similarly situated."138 As a general principle of law, however, the assertion that adequate class representation cannot be provided by a plaintiff who is unable to retain his personal standing in the action lacks merit.

Wherever representative actions are involved, it may be argued that the concepts of standing and personal stake are not coextensive and that the absence of a personal stake in the action on the part of the representative may not entail a loss of standing simpliciter. ${ }^{139}$ Ac-

135. See Mersay v. First Republic Corp., 43 F.R.D. 465 (S.D.N.Y. 1968), a class action which was held to comply with the typicality requirement even though the individual plaintiff was barred from recovery by defenses peculiar to lim which would not bar other members.

136. It has been contended that the typicality requirement has no unique content or independent importance at all. See 3B MOORE II 23.06-2: "In fact, there is no need for this clause, since all meanings attributable to it duplicate requirements prescribed by other provisions in Rule 23." Id. at 23-325.

137. See Bailey v. Patterson, 369 U.S. 31 (1962).

138. Kauffman v. Dreyfus Fund, Inc., 434 F.2d 727, 734 (3d Cir. 1970), cert. denied, 401 U.S. 947 (1971). See also Rothblum v. Board of Trustees, 474 F.2d 891, 899 (3d Cir. 1973); 7 WRIGHT \& MILLER § 1761, at 590.

139. Whenever associations, parents, trustees, corporate officers, etc., are allowed to assert the rights of others, they have standing to sue although they clearly have no personal stake in the action. See, e.g., Adler v. Board of Educ., 342 U.S. 485 (1952) (parents asserting the rights of school children); Joint Anti-Fascist Refugee Comm. v. McGrath, 341 U.S. 123 (1951) (organization asserting the rights of its inembers); Pierce v. Society of Sisters, 268 U.S. 510 (1925) (parochial school asserting the rights of its students); Brewer v. Hoxie School Dist. No. 46, 238 F.2d 91 (8th Cir. 1956) 
cordingly, it has been held that the representative of a class action need not retain a personal stake in the outcome of the action in order to satisfy the standing requirement, so long as he can provide competent representation of the controverted issues raised by the class action. ${ }^{140}$ This accords with the fact that rule 23(a)(4) makes no mention of standing or personal stake, but speaks only of an ability to provide "fair and adequate" representation as an essential attribute of a class representative..$^{141}$

Since the concept of standing itself is broad enough to encompass the recognition of a party's right of access to the federal courts as a representative of other persons' interests, ${ }^{142}$ a class representative may be said to have standing by virtue of his fulfillment of the role of a representative party. Therefore, to argue that a plaintiff may not represent a class action simply because he lacks standing is to engage in a tautology, since one cannot conclude that a party lacks standing to continue to represent the class until one first ascertains whether that party would be an adequate representative. Whether that party occupies the role of a recognizable representative is the precise question that was to be answered by reference to the requirement of standing to represent the class. Thus, the concept of standing cannot be appealed to as a bar against the plaintiff's right or ability to represent a class action where the status of being an adequate representative is one of the elements of the very concept of standing.

Standing primarily requires an assurance of adversity between the parties present to an action in order to avoid the issuance of advisory

(school board raising the rights of school children). Concerning competency to sue in a representative capacity on behalf of corporations and others, see C. WRIGHT, LAW of Federal Courts $\$ 70$, at 295-96 (2d ed. 1970); Sedler, Standing to Assert Constitutional Jus Tertii in the Supreme Court, 71 YALE L.J. 599, 626-48 (1962).

140. See McGuire v. Roebuck, 347 F.Supp. 1111, 1125 (E.D. Tex. 1972); La Sala v. American Sav. \& Loan Ass'n, 5 Cal. 3d 864, 489 P.2d 1113, 97 Cal. Rptr. 849 (1971). See also Berger, Standing to Sue in Public Actions: Is It a Constitutional Requirement?, 78 YALE L.J. 816 (1969).

141. See note 21 supra and accompanying text.

142. See note 139 supra. Cf. Barrows v. Jackson, 346 U.S. 249 (1953), where the Court provided an alternative analysis by holding that the principle of standing is linked to a court-developed rule of self-restraint which should not be applied where it would be difficult for the persons whose rights are asserted to present their grievance before any court. In Barrows a white defendant was allowed to assert the rights of all blacks against an unconstitutional racially restrictive covenant, thus presenting a situation not unlike a conveutional $23(\mathrm{~b})(2)$ class action challenging the unconstitutionahty of state action or seeking an injunction on behalf of a specific class. Thus, representatives may either be thought to satisfy the standing requirement themselves or else the doctrine of standing is arguably inapposite under the foregoing argument that restraint should not be applied so long as representation of an adverse claim is adequate. 
opinions in violation of the case or controversy requirement of article III. ${ }^{143}$ Wherever the class action has been certified as an action by the court, the case or controversy provision of the Constitution will be satisfied by the presence of the class controversy which, in those circumstances, remains following the dismissal of the named representative's claim. ${ }^{144}$ Thus, in such cases the adversity of an actual controversy clearly persists between the claims of the class and the denials of the defendant, which satisfies the adversity requirement necessary to allow the exercise of federal judicial power. Whether a particular disınissed plaintiff can thereafter adequately preserve this adverseness should be determined by examining the facts of the case to determine whether he will fairly and adequately protect the interests of the class, and not by trying to determine whether he retains personal standing.

Adequacy of Representation. Thus, whether a plaintiff can adequately represent the interests of the class is a question which must be decided purely upon the facts of each individual case. ${ }^{145}$ For this reason, the Fifth Circuit has recently advanced the theory that a dismissed plaintiff need only manifest "the nexus required by Rule 23 " in order to permit him to continue to serve as a representative of the action. ${ }^{148}$ Though the contours of this vague concept have not yet been clearly defined, they may be expected to resemble the criteria generally used in judging the adequacy of representation, including the following: the ability of the plaintiff's counsel to conduct the litigation, ${ }^{147}$ the possible presence of amici curiae in the case, ${ }^{148}$ the likehhood of collusion between the class representative and the defendant, ${ }^{149}$ the checks against antagonistic interests or disproportionate personal

143. The doctrine of standing and the requirement of a case or controversy derive from article III, section 2 of the Constitution. Association of Data Processing Serv. Organizations, Inc. v. Camp, 397 U.S. 150, 151 (1970); Flast v. Cohen, 392 U.S. 83, 101 (1968). See generally C. Wrught, supra uote 139, \& 13; Bickel, Foreword: The Passive Virtues, 75 HaRv. L. Rev. 40, 42 (1961).

144. See text accompanying notes 64,109 supra.

145. See 7 Wright \& MiLleR $\& 1765$, at 622 .

146. Francis v. Allied Serv. Co., 486 F.2d 597 (5th Cir. 1973); Huff v. N.D. Cass Co., 485 F.2d 710 (5th Cir. 1973). See notes 73-77 supra and accompanying text.

147. Eisen v. Carkisle \& Jacquelin, 391 F.2d 555, 562 (2d Cir. 1968). This consideration will vary in direct relationship to the complexity of the legal issues that need to be argued by counsel on behalf of the class. See Wymelenberg v. Syman, 54 F.R.D. 198 (E.D. Wis. 1972); Katz v. Carte Blanche Corp., 52 F.R.D. 510 (W.D. Pa. 1971).

148. See Gaddis v. Wyman, 304 F. Supp. 717 (N.D.N.Y. 1969), aff'd sub nom. Wyman v. Bowens, 397 U.S. 49 (1970). The amicus curiae briefs here teuded to insure that the class interests would be thoroughly and competently advocated and protected.

149. See Hansberry v. Lee, 311 U.S. 32 (1940); Eisen v. Carlisle \& Jacquelim, 391 F.2d 555, 562 (2d Cir. 1968); 7 Wright \& Miller $§ 1768$. 
interests on the part of the individual representative, ${ }^{150}$ and the representative's ability to protect the rights of the class under the requireinents of due process. ${ }^{151}$ In addition, a "nexus" may arise from the fact that the plaintiff had a recent and relatively thorough personal association with the situation out of which the cause of action has arisen, ${ }^{152}$ and that he was individually affected by the actions of the defendant alleged in the class action, at least to some significant extent. It is also possible that the continuing ties which the plaintiff and his attorney share with the class' community may be treated as material factors in some cases. In any event, it is not required that the "best" representative be produced in order to insure "adequate" representation of the class action, ${ }^{153}$ and this promises to be especially true when social or economic factors would make it difficult for other representatives to step forward to assume the leadership of the class. Therefore, the decision whether the nained plaintiff should be allowed to continue to serve as the representative of the class in a viable class action despite his individual dismissal from the action should rest upon the trial court's conclusion as to whether factors such as those discussed above are present in sufficient number and degree to establish this continunig "nexus" between the named plaintiff and the class.

\section{CONCLUSION}

As long as a class action procedure is available under the Federal Rules of Civil Procedure, federal courts will be confronted with problems stemming froin the inevitable disparity of individual characteristics existing among the nembers of the class. This type of problem is

150. See generally 3B MOORE If 23.07[2]; 7 WRIGKr \& MILLER $\$ 1768$. Although antagonistic or disproportionate interests on the part of the representative with respect to other members of the class may affect his ability to represent the class, courts have not gone so far as to require that his claim be identical with those of the rest of the class. See notes 14-20 supra and accompanying text.

151. See Hansberry v. Lee, 311 U.S. 32 (1940). Due process demands a fair and adequate hearing concerning the claims of the class. Criteria which the courts may take into consideration in determining whether due process will be assured under the representation of the named plaimtiff include the following: (1) the ease with which the case may be decided in terms of legal argument, Wymelenberg v. Syman, 54 F.R.D. 198 (E.D. Wis. 1972); (2) how difficult it would be for other members of the class to initiate another action de novo, Craddock v. Hill, 324 F. Supp. 183, 189 (W.D. Mo. 1970); (3) how urgent the need for relief appears to be, and whether any self-initiated conciliatory measures by the defendant have changed the underlying motivation sustaining the class action, Caplin v. Oak, 356 F. Supp. 1250 (S.D.N.Y. 1973). See also 7 WRIGHT \& MILLER § 1765, at 618 .

152. See Burney v. North Am. Rockwell Corp., 302 F. Supp. 86 (C.D. Cal. 1969). See generally 47 TULANE L. REv. 1005, 1006-11 (1973).

153. See 7 WRIGHT \& MLLER $\$ 1765$, at 620 . 
accentuated when differences arise between the legal rights vis-à-vis the defendant of the representative of the class action and those of the class itself. Whether the class action is maintainable under these circumstances and whether the named plaintiff may continue to represent the class in the action are questions which have not yet been answered by the Supreme Court. ${ }^{154}$ As the problem has arisen in several contexts, the federal courts have come to handle the issue im two mutually exclusive ways, following the prima facie attractiveness of two separate propositions: first, that a class action cannot be brought by a person who is not a member of the class, and contrariwise, that a class action over which the federal courts have jurisdiction may not be deprived its day in court merely because the named representative is no longer capable of personally participating in the class judgment. It has been argued that these basic statements are not fundamentally irreconcilable, once their precise meanings have been developed and correlated with two distinct questions concerning, first, the existence of, and second, the representation of class actions. These two questions have been shown to be logically independent of one another, since the fact that adequate representation can be assured does not necessarily imply the underlying existence of a viable class action, nor can a dismissal of the named representative terminate the rights of a class to a class adjudication once it has been (or has some exceptional right to be) properly constituted under a rule $23(\mathrm{c})(1)$ court certification. Therefore, only on the fulfillment of the separate conditions that the class action has been recognized (or is recognizable) under 23(c)(1) and that the class plaintiff continues to manifest a relationship with the class capable of insuring its adequate representation should a class action plaimtiff be allowed to continue in his representative status following the dismissal of his personal cause of action.

154. The dissent in O'Shea v. Littleton, 42 U.S.L.W. 4139 (U.S. Jan. 15, 1974), is clearly correct when it points out that the oft-quoted line to the effect that a plaintiff cannot represent a class of whoin he is not a nember, Bailey v. Patterson, 369 U.S. $31,32-33$ (1962), see text accompanying note 43 supra, is dictum and that the issues presented in this Comment have never been squarely confronted on any other occasion.

The upshot is that one crucial issue [concerning the existence of a case or

controversy in the absence of an actionable personal claim by the named plain-

tiffs], on which the Court makes this case turn has not been decided by the

Court and was never argued here. At the very least we should have a full-

dress reargument on that point. 42 U.S.L.W. at 4145.

It is suggested that "that point" embraces not one, but two crucial issues, nainely, the existence of a recognizable case or controversy before the court and the independent ability of the plaintiff to represent it. 